\title{
The Impact of Politically Connected CEOs and Boards of Directors on Firm Performance: A Study of Vietnamese Family and Nonfamily Firms
}

\author{
Accepted for publication on Entrepreneurship Theory and Practice
}

\begin{abstract}
Integrating new institutional economics and resource dependence theory, this study investigates whether in transition economies, characterized by shifting from centrally commanded to more market-oriented economies, there are performance differences among family firms (FFs), nonfamily firms (non-FFs), and former state-owned enterprises (former SOEs), and whether political connections affect these differences. Our findings suggest that FFs outperform non-FFs and former SOEs, unless non-FFs have politically connected CEOs. The performance gap in favor of FFs increases at high levels of board political connection intensity. Among FFs, the top-performing ones either promote nonfamily leadership or combine family leadership with politically connected boards of directors.
\end{abstract}

\section{KEYWORDS}

Family firm; political connection; transition economy; family CEO; board of directors; firm performance; former SOEs; Vietnam

\section{INTRODUCTION}

In the last few decades, "family capitalism" has proven to be solid and to contribute to developing national economies (Schumpeter, 2011; Luo, \& Chung, 2005). Nevertheless, it differs across cultural and national contexts (Steier, 2009). Addressing those differences means avoiding taking paradigms developed in Western economies and applying them "blindly" to family firms (FFs) from emerging and/or transition economies (Dinh, \& Calabrò, 2019). Recognizing the specific features of FFs is particularly important in emerging economies that are transitioning from a centrally planned economy to a market-oriented one (Dana, \& Ramadani, 2015; Sensoy, Ozturk, Hacihasanoglu, \& Tabak, 2017). This helps contextualize the phenomenon and the adopted theories (Gomez-Mejia, Basco, Müller, \& Gonzalez, 2020).

FFs in emerging economies are capable of filling the "institutional voids" and overcoming market inefficiencies (Chakrabarty, 2009; Ge, Carney, \& Kellermanns, 2018; 
Luo, \& Chung, 2013). In particular, they leverage their unique access to family resources and capabilities accumulated over generations, such as family social and human capital, longterm orientation, and strong emotional attachment (Basco, Calabrò, \& Campopiano, 2019), helping them to outperform their nonfamily counterparts (Jiang, \& Peng, 2011; Peng, \& Jiang, 2010).

However, it is legitimate to question whether the superior performance of FFs in emerging economies also holds in transition economies (Banalieva, Eddleston, \& Zellweger, 2015). This is because most FFs in transition economies are relatively young and facing the first succession process, in an environment characterized by active government involvement (Xu, \& Meyer, 2013). Indeed, in these economies, governments often impose their political power and tend to allocate resources favorably to their connected economic organizations, especially state-owned enterprises (SOEs) and those that are able to help them meet their developmental goals quickly and efficiently (Tang, Ye, \& Zhou, 2013; Faccio, 2006; Sharif, Kyid, \& Wei, 2015). Consequently, such an institutional context creates high resource dependencies forcing firms competing in this uncertain market to access vital and strategic resources to survive and grow (Zhou, 2013). Although some studies show that FFs can leverage their idiosyncratic advantages, such as loyalty to the family, impetus for entrepreneurial drive, informal venture capital, and smaller size enabling adaptation (Singal, \& Singal, 2011; Steier, 2009), little is known about the extent to which FFs show superior performance with respect to non-FFs and former SOEs, which represent the other major types of firms in transition economies (Singal, \& Singal, 2011). Moreover, in contexts where political consensus has a relevant role (Ovaska, \& Sobel, 2005), it is important to understand how FFs combine their idiosyncratic characteristics and political connections to navigate the uncertain and lingering institutional changes, and thus reduce resource dependencies (Wang, Ma, Song, \& Liu, 2016; Xu, Xu, \& Yuan, 2013). Therefore, this study aims to address the 
following questions: Do FFs (still) outperform other types of firms (non-FFs and former SOEs) in transition economies? To what extent does nurturing political connections (by having politically connected CEOs and/or boards of directors) contribute to better performance levels of FFs over other types of firms in this context?

Integrating arguments from new institutional economics (Williamson, 2000; Williamson, Brousseau, \& Glachant, 2008) and resource dependence theory (Pfeffer, \& Salancik, 1978; Hillman, \& Dalziel, 2003), we contend that in transition economies FFs outperform both non-FFs and former SOEs thanks to their idiosyncratic characteristics that help them navigate the institutional changes and fill the institutional voids. Furthermore, we theorize that FFs benefit from politically connected CEOs and high board of directors' political connection intensity (Faccio, 2006; Chen, $\mathrm{Li}, \mathrm{Su}, \& \mathrm{Sun}, 2011$ ) to a greater extent than non-FFs and former SOEs, thanks to a higher legitimacy and greater access to needed resources. Our hypotheses are tested on a sample of Vietnamese listed FFs, non-FFs, and former SOEs by using unbalanced panel data from 1,947 firm-year observations (2009-2018), through feasible generalized least squares (FGLS). The Vietnamese context is an ideal natural laboratory, as it is a transition economy and a single-party-run country that has undergone various political and economic reforms, and where the centrally planned economy is gradually being replaced by a market-oriented one (Dana \& Ramadani, 2015).

Our main results show that Vietnamese listed FFs outperform both non-FFs and former SOEs. However, the significance of the performance gap between FFs and non-FFs disappears when they appoint politically connected CEOs. Nonetheless, FFs benefit most from a higher performance with respect to both non-FFs and former SOEs when they appoint a politically connected board of directors. Our analyses on the subsample of FFs reveal that the ones with family CEOs underperform those with non-family CEOs. However, FFs with a family CEO achieve better performance by increasing their boards' political connection 
intensity. Our study thus suggests that, in transition economies, building and nurturing board political connections empowers FFs to use at best their family-specific resources.

Overall, the findings from this study offer a more fine-grained understanding of the performance of FFs in emerging economies (Peng, \& Jiang, 2010; Jiang, \& Peng, 2011; Manikutty, 2000) discussing the peculiar aspects of operating in a transition economy. Our contextualized approach brings into the debate the urge to differentiate FFs in transition economies from those in "traditional" emerging economies, since FFs in the former institutional context benefit from their idiosyncratic characteristics showing better performance. Following the debate on the context-sensitive approach in family business research (James, Hadjielias, Guerrero, Discua Cruz, \& Basco, 2020), we thus add to this debate the fundamental role of institutional economics when investigating performance differences among diverse firm types in transition economies (Tran, Nonneman, \& Jorissen, 2015). Hence, our findings also contribute to institutional economics advancing that the institutional environment plays a key role in shaping the economic landscape and restraining or leveraging family idiosyncrasies in a firm to outperform other types of organizations (Filatotchev, Jackson, \& Nakajima, 2013; Aguilera, \& Jackson, 2010).

Moreover, our findings complement and extend the predictions of resource dependence theory (Hillman, \& Dalziel, 2003; Pfeffer, \& Salancik, 1978) in the context of FFs in a number of ways. This study in fact emphasizes the major role of the board directors, through political connections, creating better conditions for their firms in highly resourcedependent environments (Hillman, 2005; Xin \& Pierce, 1996). Our findings also disentangle the effects of political connections among their holders. While having a politically connected CEO is not relevant for FFs, in transition economies granting resources and gaining legitimacy through politically connected directors benefits FFs in terms of performance with respect to both non-FFs and former SOEs. Finally, this study also informs practitioners and 
policymakers. FF owners should be aware that if they want to strive for success in transition economies, they should either promote nonfamily leadership or combine family leadership with politically connected directors.

\section{THEORETICAL BACKGROUND}

\section{New institutional economics and transition economies}

The core argument of new institutional economics is that "institutions matter and are susceptible to analysis" (Williamson, 1996, p. 3). Institutions provide rules, constraints, and incentives that are instrumental to governing economic exchange. Indeed, this theory asserts the importance of organizations achieving congruence with their institutional context, by emphasizing how organizations can achieve legitimacy and respond to surrounding institutional changes (Luo, Chung, \& Sobczak, 2009). Incorporating new institutional economics in investigating a phenomenon in a specific context enables researchers to show how distinct national corporate governance systems evolve from, and are aligned with, the unique cultural and political configurations and the interests of powerful institutional actors embedded in those contexts (Luo et al., 2009; Aguilera, \& Jackson, 2010). Therefore, new institutional economics offers a suitable theoretical lens through which to study firm characteristics and performance in light of the country-specific institutional characteristics and changes, given its assumptions on the role of government policies and political risk in determining firm strategies, behaviors, and outcomes (Hoskisson, Eden, Lau, \& Wright, 2000; Williamson et al., 2008). We advance that these assumptions are particularly useful in studying how different types of firms, i.e., FFs, non-FFs, and former SOEs, compete and perform in a transition economy like Vietnam, where institutional changes happen at a fast pace and significantly affect the economic environment where firms operate (Abegaz, 2005). 


\section{Reducing dependencies in a changing institutional environment}

Among the core challenges that firms face in transition economies, access to resources to facilitate their business activities is crucial. To address this critical issue in an environment characterized by institutional voids and swift changes, we integrate new institutional economics with resource dependence theory (RDT). The central emphasis of resource dependence theory is that firms face a multitude of interdependencies with external actors for accessing critical resources (Hillman, \& Dalziel, 2003; Pfeffer, \& Salancik, 1978). Therefore, firms need to procure resources from, and manage uncertainties caused by, external constituents to survive and grow (Sun, Hu, \& Hillman, 2016). Among the external constituents, the government is "one of the most difficult environmental dependencies to control" (Hillman, Withers, \& Collins, 2009, p. 9). Indeed, in transition economies, most resources are in the hands of governments and the institutional landscape features a high level of uncertainties. Previous research argues that external uncertainties and critical resources can be managed and extracted by "resource-rich" senior managers and/or board directors (Peng, 2004; Hillman et al., 2009).

Resource dependence theory suggests various mechanisms allowing firms to reduce those dependencies, such as hiring an external CEO or filling the board seats with members that can reduce the firm dependency on a certain resource (e.g., giving a seat to a member of a powerful bank if the firm needs access to financial resources) (Houston, Jiang, Lin, \& Ma, 2014; Xu et al., 2013). Thus, the networking and lobbying role of CEOs and directors, widely debated within this stream of literature, could be of utmost importance, especially if the aim is to connect firms with the government and/or main political power, which are the gatekeepers of specific types of strategic resources at the national level (Sun et al., 2016). Connecting to powerful governmental actors is one possible way to reduce resource dependencies. Political ties can, indeed, facilitate access to critical information and help 
influence political decisions, which can affect the corporate landscape as well as grant legitimacy to the business (Hillman, 2005; Hillman et al., 2009). Indeed, firms whose CEOs strengthen their long-term relationships with numerous politicians and other governmental officials (Fan, Wong, \& Zhang, 2007) in transition economies could be more competitive than other market players (Li, \& Zhou, 2005; Leuz, \& Oberholzer-Gee, 2006; Tang et al., 2013). Moreover, CEOs taking an active role in politics by becoming members of the parliament (Morck, \& Yeung, 2004), could benefit the firms they lead. CEOs' political connections cultivated through membership in political forums or trade associations (Zhou, 2013) could help develop personal relationships with regulatory agencies and politicians (Houston et al., 2014; Chung, \& Ding, 2010).

Furthermore, firms might consider appointing to the board individuals with political ties. This is particularly relevant in transition economies where some forms of organizations, which are closer to the ruling political party, might have preferential access to strategic resources (Sharif et al., 2015). Thus, firms that are left out have the incentive to create linkages with important external actors that can help them to reduce dependency and gain resource competitiveness (Hillman, 2005). In sum, in transition economies firms are prompted to create political connections by appointing to their boards individuals with political ties (Ang, Ding, \& Thong, 2013) to solicit political patronage (Chen, Li, \& Shapiro, 2011; Ge et al., 2018). Some research suggests that when there is high dependence on the government, listed firms appointing more external directors with strong political ties increase their performance (Wu, Wu, \& Rui, 2010; Sharif et al., 2015). Accordingly, firms need more than one connection to synthesize various resources, such as financing, a lower tax rate, free land use, licenses, and favorable legal treatment (Tsai, Wang, Ho, \& Lin, 2016; Le, \& Nguyen, 2009). Thus, it is vital for firms to appoint key individuals who, with their political connections, can help reduce uncertainties, manage resource dependencies, and provide 
preferential access to information (Hillman et al., 2009; Pfeffer, \& Salancik, 2003; Ge et al., 2018).

\section{HYPOTHESES DEVELOPMENT}

Drawing on new institutional economics and resource dependence theory, we advance that, in a transition economy, different types of firms (FFs vs. non-FFs and former SOEs) rely on different characteristics to reduce institutional uncertainties and changes. Moreover, we theorize that building political connections, aimed at reducing the dependencies on external constituencies, help them access the needed resources and positively affect their performance.

The debate on FFs in emerging markets has suggested that they outperform their nonfamily counterparts as they leverage the benefits of family control, which enable them to cope with the institutional voids of those markets (Peng, \& Jiang, 2010; Jiang, \& Peng,

2011). By acknowledging that governments still have a strong power in transition economies (Yiu, Bruton, \& Lu, 2005), it becomes fundamental to challenge the current understanding of the sources of advantages that FFs can leverage in traditional emerging economies. Thus, in the following sections, we incorporate the idiosyncratic characteristics of FFs in transition economies, strongly building on the knowledge about different types of family capitalism in different institutional contexts (Schumpeter, 2011; Steier, 2009).

\section{Firm performance in transition economies}

We suggest that FFs in transition economies benefit from specific advantages with respect to other types of firms. In the following sections, we thus argue why FFs outperform nonfamily firms and former SOEs. 


\section{FFs vs. non-FFs}

In a hostile environment, with a high risk of government expropriation, a dearth of legal protection, and limited access to resources (Tang et al., 2013; Faccio, 2006; Guriev, 2004; Johnson, Kaufmann, McMillan, \& Woodruff, 2000), both FFs and non-FFs face hindrances that require them to fully leverage their own idiosyncrasies to boost firm performance.

Non-FFs are believed to have advantages in dynamic environments, typically in transition economies, due to their emphasis on efficiency, flexible human resource management, and short-term goals, which make them establish new business paradigms ahead of institutional changes (Cannella Jr, Jones, \& Withers, 2015; Gedajlovic, Carney, Chrisman, \& Kellermanns, 2012). However, despite both FFs and non-FFs were legally allowed to develop in the late 1980s, it is important to know that during 1955-1975 Vietnam was divided into two countries, South Vietnam and North Vietnam. South Vietnam followed capitalist market-free economy where numerous FFs existed before being confiscated when the country was officially reunified in 1976 (Gettleman, Franklin, Young, \& Franklin, 1995). A large number of FFs from the South then restarted their business operations in 1980s when the country removed the forbiddance of private ownership (Bui, \& Nunoi, 2008; Luong, \& Diep, 1991). This means that some business families had gained business experience before being expropriated, and their business "secrets" had been maintained, passed to the next family generation, and kept by family members (Luong, \& Diep, 1991). Now they are legally allowed to be "reborn," creating an enormous desire to develop and leading to a greater commitment to develop and sustain their businesses for the wealth of their families after decades of being prohibited (Luong, \& Diep, 1991). Moreover, during lingering transitions, resources quickly erode as firms struggle to adapt to new institutional changes (Banalieva et al., 2015). In this context, only being efficient is not enough, but also being adaptive and deploying enduring resource capacity can help firms survive and prosper (McMillan, \& 
Woodruff, 2002). Specifically, given the unequal institutional developments in transition economies, institutional voids and uncertainties persist (Khanna, \& Palepu, 1997), requiring firms to develop strategies that could substitute for formal institutional support (Dinh, \& Calabrò, 2019; Ge et al., 2018).

In this institutional context, research shows that FFs have advantages over non-FFs in coping with the institutional reforms in transition economies thanks to family idiosyncratic characteristics (Banalieva et al., 2015). First, emphasis is placed on informal relationships, social capital, and trust (Chan, Makino, \& Isobe, 2010). When the access to resources through formal channels is limited, FFs are able to develop and exploit resources through informal networks and social capital (Arregle, Hitt, Sirmon, \& Very, 2007; Peng, \& Jiang, 2010; Salvato, \& Melin, 2008). They can, indeed, leverage their family status, which encourages long-term support and reciprocal relationships with different stakeholders, via more extensive connections and family ties with outside stakeholders (Miller, Lee, Chang, \& Breton-Miller, 2009). Second, the fact that family leaders are able to commit their family resources and put forward their reputational credibility or "face" (Dinh, \& Calabrò, 2019) fosters their responsibility to honor commitments and increases their organizational resilience that would make them resist even in adverse times. This echoes the literature suggesting that FFs can rely on informal and survivability capital (Steier, 2009). Third, the long-term orientation that characterizes FFs is particularly relevant in transition economies, where FFs can benefit from the alignment of interests between family shareholders and the firm (Singal, \& Singal, 2011), especially thanks to the loyalty to the family and the obligation to provide wealth for the family as a driver for being entrepreneurial (Steier, 2009). Finally, FFs are known for treating their employees with unusual consideration to form a "cohesive internal community" (Miller et al., 2009). Such intimate relationships are at the heart of the stewardship culture of FFs (Singal, \& Singal, 2011) that, in transition economies, are 
believed to compensate in the long run for the lack of institutional infrastructure (Miller et al., 2009; Ge et al., 2018), helping them overcome lingering institutional challenges (Banalieva et al., 2015; Chan et al., 2010).

These arguments would suggest that FFs have a unique opportunity to build on their family idiosyncrasies, which would put them in a stronger position to outperform non-FFs in transition economies. Therefore, we hypothesize:

Hypothesis 1a: In transition economies, listed family firms outperform nonfamily firms.

\section{FFs vs. former SOES}

Besides non-FFs, FFs in transition economies coexist with former SOEs. Soon after private firms were allowed to populate the market, governments in transition economies also restructured their SOEs to rescue poor-performing SOEs via the mechanism of privatization or equitization (Nguyen, \& Van Dijk, 2012; Vo, Swierczek, \& Nguyen, 2013). It was expected that equitization would change the ownership of SOEs, attract more investments from the private sector, and improve the performance of these former SOEs (Vo et al., 2013).

Despite the effort, privatization of SOEs, especially in Vietnam, has remained modest and is found to target small SOEs and not larger ones, thus not addressing the efficiency problem (Sjöholm, 2006). Although ownership and management structures in former SOEs have changed to a certain extent, governments often retain their control by remaining as block shareholders and appointing politicians or state representatives in senior leadership positions (Vo et al., 2013). The continued interference of governments is often associated with mismanagement resulting from coalition between managers and politicians in former SOEs (Carney, \& Hamilton-Hart, 2015), who maneuver the companies just for their personal gain (Fan, Wei, \& Xu, 2011; Shleifer, 1998). Indeed, their activities are often driven by sociopolitical goals, which are at odds with shareholders' wealth maximization (Singal, \& 
Singal, 2011). Furthermore, the emergence and changes in ownership and management in former SOEs often lead to new organizational complexity and conflicts between new and existing shareholders (Tran et al., 2015). These governance inefficiencies are reflected in the very low productivity of this type of corporation (Fan et al., 2011). As a result, it takes time for former SOEs to adapt to their new institutional economic environment and be relatively competitive with respect to private firms, including FFs (Loc, Lanjouw, \& Lensink, 2006).

In contrast to former SOEs, FFs leverage on aligned objectives between family shareholders and their firms. They exhibit a stewardship orientation that fosters motivation based on higher commitment to the firm and a higher degree of trust, thereby reducing opportunistic behavior (Singal, \& Singal, 2011), as "one does not steal his own money" (Peng, \& Jiang, 2010, p. 255). Additionally, family commitment can support enhanced organizational responsiveness, facilitating the identification and rapid exploitation of profitable opportunities (Miller, \& Breton-Miller, 2006; Zahra, Hayton, Neubaum, Dibrell, \& Craig, 2008) in transition economies. Hence, we hypothesize:

Hypothesis 1b: In transition economies, listed family firms outperform former SOEs.

\section{The moderating role of political connections in reducing resource dependencies}

As mentioned before, the institutional environment in transition economies poses several challenges, due to the immature economic institutions and continuous changes in laws and regulations (Young, Peng, Ahlstrom, Bruton, \& Jiang, 2008). Firms face a shortage of resources (Opper, 2008) and need to seek alternatives to secure strategic resources to reduce their dependencies on the environment. In transition economies, firms that secure political consent have a higher likelihood of sustaining their business (Ovaska, \& Sobel, 2005). Accordingly, and in line with the predictions of new institutional economics and resource dependence theory, political ties can substitute for inadequate market infrastructure and 
reduce transaction costs (Peng, \& Luo, 2000; Xin, \& Pearce, 1996; Zheng, Singh, \& Chung, 2017).

In the following sections, we discuss the benefits that FFs can achieve by having politically connected CEOs and boards of directors to boost their performance with respect to non-FFs and former SOEs in transition economies.

\section{Politically connected CEOs and FF' performance}

We distinguish between political ties established by the CEO and by the board of directors. CEOs can be particularly capable of managing resource dependencies (Finkelstein, Cannella, Hambrick, \& Cannella, 2009) that have been proved to be highly relevant during institutional transitions (Li, Meng, Wang, \& Zhou, 2008; Peng, \& Luo, 2000; Shi, Markóczy, \& Stan, 2014; Li, \& Zhang, 2007). Thanks to their political ties, they have access to a better set of strategic resources that have a greater impact on firm performance (Young, \& Tsai, 2008; Li et al., 2008).

FFs can particularly benefit from politically connected CEOs. First, given that FFs rely on the interest alignment of family shareholders and the business itself, having politically connected CEOs can help access critical information on regulatory changes at an early stage (Chung, \& Ding, 2010), thus making them choose strategies to ensure the pursuit of familycentered objectives. Moreover, their typical long-term orientation makes FFs view political connections as their specialized assets (Bennedsen, Fan, Jian, \& Yeh, 2015) that they would like to pass to the next generation (Bertrand, \& Schoar, 2006; Xu, Yuan, Jiang, \& Chan, 2015). Thus, family owners tend to handle political connections with care (Dou, \& Li, 2013), nurturing and preserving them without merely exploiting and exhausting them (Liu, Luo, \& Tian, 2015). The CEOs' political ties or their own participation in the political life of the 
country are incorporated into the unique social capital of FFs, which they can better nurture and leverage on, as part of their family advantage.

This can be significantly important, especially in comparison with non-FFs that tend to exploit such political connections for short-term objectives (Qian, Pan, \& Yeung, 2011) or former SOEs whose managers are motivated by their individual interests (Fan et al., 2011; Shleifer, 1998). Indeed, in non-FFs, political connections are associated with worse performance (Fan et al., 2007). The "grabbing hand" between majority shareholders and politicians leading to severe expropriation of minority shareholders in non-FFs and former SOEs led by politically connected CEOs significantly and negatively influences firm value and performance (Cheung, Jing, Rau, \& Stouraitis, 2005; Berkman, Cole, \& Fu, 2011). Additionally, the continued political interference in former SOEs may conflict with the new shareholders' profit maximization goal and impede improvement efforts, thereby being detrimental rather than beneficial (Boubakri, Cosset, \& Saffar, 2008; Leuz, \& OberholzerGee, 2006). In sum, political connections in FFs can complement their family-specific idiosyncrasies in transition economies and sustain their performance with respect to non-FFs and former SOEs in transition economies (You, \& Du, 2012; Zhou, 2013). In other words:

Hypothesis 2: In transition economies, having politically connected CEOs strengthens the superior performance of listed family firms with respect to non-FFs and former SOES.

\section{Board of directors' political connection intensity and FFs' performance}

In the above-presented theoretical background, we consider the critical role played by boards of directors in managing external resource dependencies by procuring access to strategic resources (Hillman, \& Dalziel, 2003; Hillman, 2005; Pfeffer, \& Salancik, 1978). Board directors use their networks and their standing to gain and maintain legitimacy and influence within the political circles they belong to (Hillman, \& Dalziel, 2003; Hillman, 2005), which in return could positively affect firm performance. 
In the continuously changing institutional environment, FFs benefit most from boards of directors' political connection intensity. Securing the needed resources would help FFs back up their family idiosyncrasies, leveraging their business "secrets" that reside in the family (Luong, \& Diep, 1991) and accessing the network that can maximize the exploitation of the accumulated knowledge. However, one director cannot possess connections that open up all types of resources and gain the legitimacy that FFs might need to survive in their competitive arena. Thus, appointing multiple directors, with several political ties, leading to multiple interlocking directorships (Lester, \& Cannella, 2006), could significantly reduce resource dependencies (Hillman, 2005; Pfeffer, \& Salancik, 1978). In fact, laws and legal enforcements in transition economies are either weak or absent, and disputes among parties are likely to happen (Young et al., 2008). In these situations, having directors with political ties can provide FFs with the needed legal protection (Chen, Cheung, Stouraitis, \& Wong, 2005) to avoid legal actions, secure political bailouts (Faccio, Masulis, \& McConnell, 2006), or reduce the cost of dispute settlements (Tang et al., 2013; Sun et al., 2016). Moreover, in the context of resource scarcity, having multiple connected directors would offer FFs different resources, including favorable interest and tax rates and/or free use of land, obtaining licenses more easily, and facing less bureaucracy (Xu et al., 2013; Adhikari, Derashid, \& Zhang, 2006; Li et al., 2008). This concerted lobbying activity by board directors complements and strengthens the available informal capital that FFs rely on to navigate the continuous and lingering institutional changes in transition economies (Steier, 2009; Banalieva et al., 2015).

These political actions by boards of directors could also benefit non-FFs and former SOEs, but to a limited extent. This is because non-FFs pursue short-term goals that might become quickly obsolete in light of the lingering changes in the economic landscape, and former SOEs that suffer from detrimental activities by their management and severe 
overinvestment problems (Braendle, Gasser, \& Noll, 2005). In sum, political connection intensity at the board level benefits FFs' performance with respect to non-FFs and former SOEs because of the board directors' ability to access resources and represent the business interests in political circles. Thus, this complements the idiosyncratic resources of FFs with vital networks and helps gain legitimacy. Considering the foregoing, we state:

Hypothesis 3: In transition economies, high board political connection intensity strengthens the superior performance of listed family firms with respect to non-FFs and former SOEs.

\section{METHODS AND ANALYSES}

\section{Contextualizing the institutional and governance landscape in Vietnam}

Vietnam differs from other emerging economies in Southeast Asia due to its historical development. Vietnam declared its independence from French Indochina and announced the creation of the "Democratic Republic of Vietnam" in 1945 and followed communist regime. However, during 1955-1975, South Vietnam declared its independence from the North and named the "Republic of Vietnam" and followed capital list market-free economy (Gettleman et al. 1995). After the country's reunification in 1976, the whole nation continued the communist regime and private ownership was forbidden (Nguyen, \& Van Dijk, 2012; Bui, \& Nunoi, 2008). In 1986, the Vietnamese government introduced a program of national economic reform (Doi Moi) with the aim of fostering economic growth. In 1990, the Law on Private Enterprises came into effect forcing the government to restructure and privatize (also known as "equitization" or "recapitalization") poor-performing SOEs (Bui, \& Nunoi, 2008; Nguyen, \& Van Dijk, 2012) and allowing private firms to develop (Bui, \& Nunoi, 2008), paving the way for developing the transition economy of Vietnam as we know it today (Sjöholm, 2006). These institutional changes, however, did not lead to immediate positive effects in the following years as they needed a long time to be implemented, and still need 
amendments (Phung, \& Hoang, 2013). In this economic landscape, the largest number of listed firms on the two stock markets in Vietnam, Ho Chi Minh and Hanoi stock markets (HoSE and HNX, respectively), are mainly privatized SOEs. Although these firms have now become "nonstate" firms (also called "former SOEs") after selling shares to public investors, the state remains a block shareholder (HoSE, 2014). The rest are family-controlled firms and non-FFs (Robinett, Benedetta, \& Nguyet Anh, 2013).

The private sector (i.e., FFs and non-FFs) has contributed significantly to the Vietnamese economy. Experiencing growth from almost nothing before 1990, the Vietnamese private sector produced $66 \%$ of the total industrial output in 2000 , and nearly $73 \%$ in 2004 (GSO, 2005). Private firms accounted for approximately 97\% of the total number of enterprises, employed nearly $77 \%$ of total employment, and contributed to the economy with $41 \%$ of GDP (Can, 2017). However, the vast majority (about 90\%) of private firms are small and medium-sized (Hakkala, \& Kokko, 2007).

Despite its progress, the Vietnamese economy still carries the main characteristics of a transition economy (Do, \& Wu, 2014), and private firms in this country suffer from political and social discrimination. The overall political environment has indeed remained antipathetic towards privately owned firms. The State Securities Commission of Vietnam tends to give priority for listing to SOEs and firms in which SOEs have a stake while private firms must fulfill more requirements ( $\mathrm{Su}, \mathrm{Xu}, \&$ Phan, 2008). As a result, this leads to a lower amount of private firms being listed on the stock exchange. Additionally, the development of private firms has been hampered by limited access to external resources ( $\mathrm{Li}$ et al., 2008; Wu et al., 2010), red tape, and tax burdens (Johnson, Schnatterly, Johnson, \& Chiu, 2010; Guriev, 2004). If disputes arise, decisions are made in favor of SOEs or former SOEs (Le Minh, \& Walker, 2008; Morck, \& Yeung, 2004). 
The corporate governance of a Vietnamese listed firm is similar to that of a firm listed according to the Australian and the British company law, a shareholding company in Chinese company law, and an AG in German company law (Le Minh, \& Walker, 2008). The corporate governance structure of a listed firm in Vietnam typically encompasses: 1) shareholders' meetings (also called "general meetings of shareholders"); 2) a board of directors; 3) a supervisory board (also called a "control board"); and 4) a general director or CEO. In this sense, the governance structure of listed firms in Vietnam follows a two-tier system, including both a board of management and a supervisory board (Bui, \& Nunoi, 2008; Tran, Koufopoulos, \& Warner, 2014). However, unlike the German supervisory board, which has strong power and can appoint and dismiss members of the board of management, the supervisory board in Vietnamese listed firms actually plays a limited and indirect role. Their monitoring role over the management board is usually bypassed by controlling shareholders (Adhikari, \& Le, 2014). In contrast, the board of management has a more direct role in the firm's operations and can make recommendations to the shareholders' meeting (Le Minh, \& Walker, 2008). The management board consists of a chairperson, executive and nonexecutive directors.

This study focuses on the board of management (also called "board of directors") and the CEO. This is because members of this board, including the chairperson and the CEO, are the ones who are likely to have political connections in the firm. They have direct impact on the strategic orientation of the firm, and are highly involved in the daily operational and managerial decision-making processes (Le Minh, \& Walker, 2008). Moreover, it is very common for members of the board, including the chairperson, to simultaneously occupy other managerial positions (e.g., CEO or division manager). 


\section{Data, sample, and variables}

Our sample consists of nonfinancial Vietnamese firms listed on the Hanoi Stock Exchange (HNX) and Ho Chi Minh Stock Exchange (HoSE) from 2009 to 2018 as provided by Vietstock (http://vietstock.vn). Since this study focuses on political connections, we exclude listed SOEs ultimately controlled by the government (owning more than 51\%), because political connections in (these) SOEs are imposed by the government rather than sought by the firms. Information on political connections is manually collected from the firms' annual reports and corporate governance reports. Moreover, such information is triangulated with other sources, including online newspapers covering finance and stock market information. We merge the data collected manually with data provided by Vietstock (e.g., return on assets and other financial variables) to obtain the final database. Our final sample represents an unbalanced panel data set with 1,947 firm-year observations from 200 firms.

Dependent variable. Firm performance is measured by using return on assets (ROA), which is one of the most common measures used in corporate governance studies (Li et al., 2008; Wu et al., 2012).

Independent variables. To test our hypotheses, four main predictors are constructed. First, the variable types_of_firm distinguishes among FFs, non-FFs, and former SOEs. Accordingly, a firm is defined as FF if (i) the family owns at least 5\% of the firm's shares, and (ii) the ultimate controlling shareholder is a family member and/or this family member is simultaneously involved in the firm's senior leadership (e.g., CEO, chairperson, board member, and/or member of the TMT). This is a standard criterion for analyzing listed FFs (e.g., Chrisman, \& Patel, 2012; Sirmon, Arregle, Hitt, \& Webb, 2008). Former SOEs are detected by looking at the firm's history published on the website of cafef.vn, which tells us in which year the firm was established and what ministry governed it, and in which year it was privatized. By checking the shareholder structure, we assess whether the government 
remains a shareholder with more than $5 \%$ and up to $49 \%$ of shares. We also check whether state employees are involved in senior leadership positions. When listed firms have the government currently owning between $5 \%$ and $49 \%$ of the shares and there are still state representatives in senior leadership positions, this means that these firms were previously SOEs. In this case, we label them as former SOEs. Finally, non-FFs are those listed firms that are not former SOEs and have no current family involvement in leadership and ownership. Therefore, our types_of_firm variable takes the value of 1 when the firm is an FF, 2 when the firm is a former SOE, and 3 when the firm is a non-FF. From this categorical variable (types_of_firm), we create three dummy variables - family_firm, nonfamily_firm, and former_SOE - that take the value 1 when the firm is classified, respectively, as an FF, nonFF, and former SOE, and 0 otherwise. Additionally, to explore family firm heterogeneity for the FF sample, we create a variable called Family_CEO that takes the value 1 when the CEO is a member of the owning family, and 0 otherwise.

We gather information on political connections from different sources. However, the main source was the cafef.vn website, which provides background information on education, and the previous and current careers of board members and CEOs. To define whether a firm has political connections, we consider whether (i) the CEO (Tang et al., 2013) or their immediate relatives (e.g., father, mother, sibling, spouse, and adult children) (Li et al., 2008) and/or (ii) board members were or are currently politicians, officials of the government, industry bureaucrats, military officers (Li, He, Lan, \& Yiu, 2012), or members of policy forums and/or trade associations (e.g., Vietnam Chamber of Commerce and Industry) (Chung, \& Ding, 2010). This information is manually collected and we use two variables to proxy political connections: politically connected CEO and board of directors' political connection intensity. 
The variable politically_connected_CEO is a dummy variable that takes the value 1 if the CEO meets one of the aforementioned political connection criteria, and 0 otherwise. The variable board of directors' political connection intensity measures the degree of political connections in the boardroom. Unlike previous studies on political connections, which investigate "low" and "high" levels of connections, for instance leading cadre vs. local cadre (Zhou, 2013), "direct" and "indirect" connection, or connected through a top government officials vs. connected through a friend (Faccio et al., 2006), our article examines the board political connection intensity. Board political connection intensity is measured by considering the number of board members that meet the political connection criteria divided by the total number of directors. The CEO is not counted when appointed in a dual function.

Control variables. We use several control variables. First, firm age, measured as the logarithm of years since the firm was founded, is included as more established firms could have better levels of ROA (Chu, 2009). Second, firm size, measured as the logarithm of total assets, may also affect ROA (Cai, Luo, \& Wan, 2012) since bigger firms are more prepared to exploit economies of scale. Third, firm leverage, measured as total debt divided by total assets (Cheng, Lin, \& Wei, 2015), could influence performance because high leverage would increase firms' interest payment costs and may thus harm firm performance. We also control for CEO duality to avoid the dual power effect on performance (Li et al., 2012); yet, board size is controlled to capture the relative effect of politically connected directors without the difficulties associated with interpreting ratio variables (Hillman, 2005). Finally, for FFs only we calculate the percentage of shares held by family members (\% Family_Ownership) as an additional control variable measuring ownership concentration that could affect our dependent variables (Mazzi, 2011). Finally, at the individual level, we add CEO_Age, measured in years, which could affect firm performance because of accumulated CEO experience (human capital proxy). Table 1 provides a list of variables used in this study. 
--- Insert Table 1 about here ---

\section{Data analysis}

We test our hypotheses using panel data by considering firm-year as the unit of analysis. Following Baltagi and Wu (1999) and Desender, Aguilera, Lópezpuertas-Lamy and Crespi (2016), we adopt the feasible generalized least squares (FGLS) regression model, which provides reliable estimates in the presence of heteroscedasticity (Wooldridge, 2002). This technique allows estimation in the presence of autoregressive, $\operatorname{AR}(1)$, disturbances within panels and cross-sectional correlation and heteroscedasticity across panels. Indeed, the models are pretested for autocorrelation using xtserial (Drukker, 2003) and the results show the significant statistic for the presence of serial correlation. Furthermore, for our specific data set, this regression technique has a number of advantages over fixed effects (FE) estimation. First, FE estimation requires significant within-panel variation of the variable values to produce consistent and efficient estimates (Desender et al., 2016). Second, FE estimates may aggravate the problem of multicollinearity if solved with least squares dummy variables (Baltagi, Bratberg, \& Holmås, 2005). Third, FE typically produces biased estimates of the fixed effects when the time period is relatively short (Jensen, \& Zajac, 2004; Chintagunta, Jain, \& Vilcassim, 1991). Finally, our variable of interest (type of firm) is time invariant. Since the study uses a panel data set, dummy variables for years (to capture year fixed effects) and industries (to control for industry fixed effects) are included in the models (Joh, 2003). The inclusion of year and industry fixed effects allows the inherent heterogeneity in strategic orientation across years and/or industries to be addressed.

We further check the probability of reverse causality as a source of endogeneity. We could not find instrumental variables to satisfy the necessary validity criteria to be applied in our models. Thus, we control for this potential problem by using lagged independent 
variables. Additionally, although we do not believe that ROA is going to affect the family status of the firm, it could affect family ownership since nonfamily investors may be attracted to firms with higher profitability. Furthermore, ROA could affect the board of directors' political connection intensity as profitable firms could be more attractive to well-connected board members. Following Yoshikawa and Rasheed (2010), we do not find that ROA explains changes in family ownership (percentage of shares) and boards of directors' political connection intensity. We examine variance inflation factors (VIFs) to exclude potential biases in the regression models. VIF values are lower than the cutoff point of 10, indicating that multicollinearity is not a significant problem (Cai et al., 2012; Netter, \& Knut, 1990).

\section{RESULTS}

Table 2 provides descriptive statistics and the correlation matrix for all variables used in this study. Listed FFs account for almost 30\% (60 firms and 592 firm-year observations), non-FFs account for 51\% (102 firms and 981 firm-year observations), and former SOEs account for 19\% (38 firms and 374 firm-year observations). Our sampled FF operate in most of major economic sectors in Vietnam, especially in agriculture and fisheries, footwear and textile, trade, construction and real estate, pharmacy and medical equipment manufacturer. Some others operate in confectionary, steel manufacturing, printing and packaging industry.

--- Insert Table 2 about here ---

With regard to political connections, while $28 \%$ of the sampled firms have politically connected boards (this percentage varies slightly from one year to another, and is not shown in Table 2 and was calculated based on the number of firms with at least one board member connected), around $46 \%$ of the cases have politically connected CEOs. This latter percentage is higher than the one reported by Fan et al. (2007), which is $28 \%$ of CEOs in 617 publicly listed companies in China between 1993 and 2000 that have political connections. These 
findings indicate a higher propensity of Vietnamese firms to build and rely on political connections. As regards the subsample of listed FFs, $28 \%$ of the FFs have at least one politically connected board member and $39 \%$ have a politically connected CEO.

The results of FGLS regressions are reported in Table 3 for the overall sample. In Model 1, we introduce all control variables. In Model 2, we add our main explanatory variables (family_firm is used as control group to be compared with the two dummy variables introduced in the equation that account respectively for nonfamily firm and former SOE) and find that FFs outperform non-FFs $(\beta=-.898, \mathrm{p}<.05)$ and former SOEs $(\beta=-1.013, \mathrm{p}<$ .001). Therefore, these findings support Hypothesis 1. Additionally, we observe that having a politically connected CEO (CEO_connected) or high board of directors' political connection intensity (board_political_connection_intensity) is positively and significantly related to return on assets $(\beta=.422 \mathrm{p}<.1$ and $\beta=2.573 \mathrm{p}<.05$, respectively).

Model 3 introduces the interaction term between types of firms and politically connected CEOs to test our Hypothesis 2. The proposed interaction produces six possible combinations, and to perform our analysis we leave one combination out (i.e., Family Firms*CEO_Connected) as a reference group. We partially find support for our Hypothesis 2. While we did not find that FFs with politically connected CEOs outperform non-FFs with politically connected ones $(B=-0.550$ but not significant $\mathrm{p}<.254)$, they did outperform former SOEs with politically connected CEOs $(B=-1.424, p<.004)$. Post estimation analyses show that the effect size of the moderation is low; however, the small effect size is common in psychology and management fields (Aguinis, Beaty, Boik, \& Pierce, 2005; Aiken \& West, 1991). To visually interpret the moderation, Figure 1 shows the six possible interactions between types of firms and politically connected CEOs. It is interesting to observe that non-FFs benefit most in terms of performance when having politically connected CEOs. 
--- Insert Figure 1 about here ---

Model 4 shows the interaction term between types of firms and board of directors' political connection intensity to test Hypothesis 3. Both coefficients are negative and significant $(\beta=-9.851 \mathrm{p}<.01$ and $\beta=-10.540, \mathrm{p}<.01)$, suggesting that FFs with a high intensity of political connections within their boards outperform non-FFs and former SOEs with high political connection intensity in the boards, thus supporting Hypothesis 3 . We plot these interactions in Figures 2 and 3. Figure 2 shows that FFs benefit most from having politically connected board members (i.e., the higher the board political connection intensity, the higher the firm's performance gap in favor of FFs). To understand better the interaction effect compared to non-FFs and former SOEs, Figure 3 shows the conditional marginal effect of FFs vs. non-FFs as well as FFs vs. former SOEs at different levels of board of directors' political connection intensity. While FFs have better firm performance, the performance gap is significant with respect to non-FFs and former SOEs when board political connection intensity is higher than about $15 \%$.

--- Insert Table 3 about here ---

--- Insert Figure 2 and 3 about here ---

\section{Exploring heterogeneity within the group of family firms}

FFs are not homogeneous entities (Chua, Chrisman, Steier, \& Rau, 2012), and looking at whether their performance could vary depending on whether the CEO is a family member or not (Jiang, \& Peng, 2011), we further investigate what makes FFs successful. Table 4 shows the FGLS regressions for FFs only. In Model 1, we introduce our control variables and in Model 2 the main explanatory variable Family_CEO. The Family_CEO coefficient is negative and significant $(B=-2.069, p<.001)$, showing that in transition economies having a family CEO is negatively related to firm performance. In Model 4, we introduce the 
interaction term between having a family CEO and board political connection intensity. This is positive and marginally significant $(B=10.424, \mathrm{p}<.10)$. Figure 4 shows the moderation effect of board political connection intensity on the relationship between a family CEO and firm performance. To better interpret this relationship, Figure 5 shows the conditional marginal effect between a family CEO and nonfamily CEO at different levels of board political connection intensity. The lower firm performance associated with having a family CEO is compensated for when FFs incorporate politically connected board members.

--- Insert Table 4 about here ---

--- Insert Figures 4 and 5 about here ---

We also perform some robustness checks. We first use a different measure for firm performance, i.e., return on equity (ROE), and our results remain consistent when using it as an alternative dependent variable. Second, to see if our results are stable when changing the time period and they are not driven by any specific event, we run our model by removing one, two, and three years and there are no significant changes in our results, i.e., our results are stable over time. Those additional tests are available upon request.

\section{DISCUSSION}

The aim of this study is to investigate whether FFs perform better (as commonly found in emerging economies) or worse than non-FFs and former SOEs in transition economies. We argue that in the context of high resource dependencies resulting from changing and adapting economic institutions (Williamson et al., 2008; Williamson, 2000), FFs may still outperform both non-FFs and former SOEs thanks to their family-related idiosyncrasies (Steier, 2009; Singal, \& Singal, 2011), which grant them significant advantages (Ge et al., 2018; Luo, \& Chung, 2005). Furthermore, we also investigated the extent to which having politically 
connected CEOs and/or boards of directors could further support FFs in managing their resource dependencies on governments and help them overcome the disadvantages in terms of access to resources in transition economies.

In line with our theoretical reasoning, we find that FFs outperform both non-FFs and former SOEs. First, these findings support our argumentation that FFs can leverage better on their family idiosyncrasies, i.e., a stewardship culture, family loyalty and obligation to business, and the ability to nurture and exploit more efficiently their social and survivability capital making them more resilient than non-FFs in transition economies. Additionally, the outperformance of FFs as compared to non-FFs in the context of the Vietnamese transition economy can also be explained by the fact that FFs had already generated business experience before the communist regime (Luong, \& Diep, 1991; Dang, \& Vo, 2019). Unlike non-FFs, FFs aim to nurture, preserve, and transmit family legacy (Rutherford, \& Kuratko, 2016; Hammond, Pearson, \& Holt, 2016); thus, they have a greater ability to maintain that previously acquired experience within the family, and then transfer the accumulated knowledge and "business secrets" to the next family generation. Indeed, there are FFs that existed before the centrally commanded economy. Soon after the economic liberation, these business families resumed their business (Luong, \& Diep, 1991; Dang, \& Vo, 2019). Thus, business families can leverage those non-tradable features that engender those idiosyncrasies to outperform non-FFs.

Second, FFs also outperform former SOEs, thus supporting the view that former SOEs might suffer from inefficiencies and goal diversity. In fact, SOEs in Vietnam have been identified as being responsible for the stagnant economy leading to numerous privatizations of inefficient SOEs at the beginning of the 2000s (Nguyen, \& Van Dijk, 2012), with politicians aiming at goals that are misaligned with shareholders' wealth maximization (Singal, \& Singal, 2011). Despite some evidence showing that performance in former SOEs 
is improved, this improvement is only acknowledged among themselves when considering pre- and post-privatization (Tran et al., 2015; Loc et al., 2006). Moreover, the transformation from state-owned to privately owned entities required time to adopt new organizational structures and adapt to more liberalized market conditions. Indeed, there are studies suggesting that the performance of former SOEs was improved if they actively implemented organizational integration, and those with less state ownership performed better (Vo et al., 2013). Conversely, recently established FFs might leverage more energetic impetus in addition to leverage on their family-related characteristics (Steier, 2009). As a result, FFs spare no effort and take up all of their opportunities to develop.

However, as is evident in Figure 1, we find that non-FFs (instead of FFs) benefit most from having politically connected CEOs, who help them close the performance gap with respect to FFs. This suggests that CEOs' political ties in FFs do not represent a significant contingent effect to boost FF performance. This finding is intriguing and casts further questions for future research to look closer into this matter. Nonetheless, possible explanation for this finding could be that, in non-FFs connected CEOs are free, at greater extent, to have their political resources incorporated in their strategies without being scrutinized by "big brother eyes" (the owning families). Yet, the performance improvement in non-FFs with politically connected CEOs is also consistent with the prediction of RDT. On the other hand, as argued earlier, FFs tend to handle political connections with care and avoid exploiting or exhausting them. Thus, connected CEOs in FFs may need to get "approved" by owning families when they want to exploit such resources through political connections. The "big brother eyes" may delay political resource implementation, thus, leading to the insignificant effects of connected CEOs in FFs.

As predicted, our results suggest that the performance gap between FFs and non-FFs as well as between FFs and former SOEs becomes higher when the political connection 
intensity of the board increases. Having politically connected directors on the board helps listed FFs solicit political patronage to protect their interests, and gain legitimacy and access to resources (Hillman, 2005; Li et al., 2008). Indeed, a multiple-connected board provides owning family with a filter mechanim allowing FFs to recheck, reflect and finally ratify what the strategic directions that were proposed by the CEOs. This practice combines with the unique FF idiosyncratic features, including family direct involvement, family loyalty and commitment (Basco et al., 2019; Steier, 2009; Jiang, \& Peng, 2011), enabling FFs to outperform their counterparts. Additionally, FFs often view political connections as a special asset, especially when operating in economies where institutions change and evolve rapidly (Zheng et al., 2017; Zhou, 2013). Therefore, family owners might particularly want those political connections to grow, be nurtured, expanded, and hopefully be passed down to the next generations (Xu et al., 2015). Furthermore, family owners often develop more personal and more extensive relationships (Dou, \& Li, 2013; Miller et al., 2009), engaging in longterm exchanges with the intention to include them in their "family guanxi circle" (Chen, \& Chen, 2004; Dinh, \& Calabrò, 2019; Dinh \& Hilmarsson, 2020). This helps FFs secure the trust of these actors who, in return, are more prone to act in favor of FFs in the long run (Miller et al., 2009). Meanwhile, politically connected directors may prefer to develop a mutual and long-term relationship with FFs as they see those firms as a new form of capitalism with the potential to develop into the main and sustainable economic force of the country.

Given that not all FFs are alike, we further explored possible performance differences in the FF subgroup between FFs with nonfamily leadership and those with family leadership. Our findings suggest that FFs with family CEOs have a lower performance with respect to their peers with nonfamily CEOs, independently of political connections. To better understand this finding (Figure 3), it is necessary to contextualize it within the Vietnamese 
economy. On the one hand, most Vietnamese FFs are in their first generation. Family legitimacy and networks are still too underdeveloped to be a source of highly competitive advantage to be exploited by family CEOs. On the other hand, FFs may be too busy to prepare for their first succession (Viet, 2015) in which exiting family CEOs need to prepare the business for their descendants, while young family leaders learn to accumulate experience. Additionally, although family CEOs may have political connections through participating in politics, connected family CEOs are new and may be inexperienced in a fierce political arena in transition economies. Furthermore, it may require family firms to invest a tremendous amount of time and can be expensive in order to obtain such highly ranked and powerful political positions (Zhou, 2013). Yet, lower-ranked political ties (e.g., obtaining membership in policy forums and/or in trade associations) might be easier and less expensive for FFs to achieve; these lower-ranked connections, however, might not have a significant impact on firm performance. Thus, to counterbalance the lower performance in the presence of family CEOs and avoid the insignificant impact of their political connections, hiring an external CEO seems to be a viable way to reduce resource dependencies. This also resonates with the RDT prediction of the central role of external CEOs in reducing such dependencies (Hillman, \& Dalziel, 2003; Pfeffer, \& Salancik, 1978).

Nevertheless, additional analyses within the FF sample also suggest that FFs led by a family CEO could boost performance if they have boards with high political connection intensity. Hence, FFs that combine a family CEO with highly politically connected directors could help reduce resource dependencies in transition economies (Xu et al., 2015; Xu et al., 2013; Wu, Wu, Zhou, \& Wu, 2012). Indeed, the fact that boards have the role of connecting FFs with core external stakeholders would allow family CEOs to focus on their "full-time job" in implementing the firm's strategy and preparing the next generation to take over, rather than channeling their resources to build personal political connections in this context. 


\section{Contributions and implications}

This study makes theoretical and practical contributions. First, by bringing into the debate the need to differentiate between emerging and transition economies when investigating performance differences between FFs and non-FFs, we further contend the fundamental role of institutional contexts that shape the economic landscape where different types of firms operate (Williamson, 2000; Williamson et al., 2008). Various new economic institutions embedded in transition economies play a key role in restraining or leveraging family specificities in the firm (Filatotchev et al., 2013; Aguilera, \& Jackson, 2010; Banalieva et al., 2015; Steier, 2009). By contextualizing the embedded institutional environment, we delineate performance differences between FFs vs. non-FFs as well as between FFs vs. former SOEs. Thus, through the lens of the new institutional economics, we are able to differentiate FFs from "traditional" emerging economies. We shed further insights into family characteristics in transition economies with respect to the arguments to discuss the superior performance of FFs in emerging markets, which mainly rely on accumulated bundles of resources and capabilities in the hands of multigenerational families. In transition economies, FFs can leverage on loyalty to the family, obligations to provide wealth for the family, stewardshiporiented leadership, and the enormous desire to survive and grow after decades of being prohibited (Steier, 2009; Dang, \& Vo, 2019).

Second, findings in this article complement and extend the predictions of RDT (Hillman, \& Dalziel, 2003; Pfeffer, \& Salancik, 1978), with a focus on the role of the board of directors in securing essential external resources through political connections. Our findings implicitely suggest that, in order to be successful and best use their idiosyncratic characteristics, FFs need to gain external legitimacy through political connections (Zheng et al., 2017). Yet, it is fundamental to distinguish between politically connected CEOs and board directors. Seeking strategic resources by bringing into the FFs politically connected 
directors, and developing and nurturing them through a unique "familial way," in fact reduces dependencies (Hillman, 2005) by decreasing political discrimination (Xu et al., 2013), securing legal protection (Tang et al., 2013), and accessing resources for growth (Faccio, 2006; Li et al., 2008). This practice enables FFs to sustain their superior performance with respect to other firm types in a new institutional economic environment. Additionally, our study enriches the governance literature in different ways. Most studies on boards of directors have mainly focused on the size of the board and/or the directing and monitoring roles played by executive vs. nonexecutive directors (Tran et al., 2014; Min, 2013; Prabowo, \& Simpson, 2011; Solomon, Lin, Norton, \& Solomon, 2003). Our study shows that the board political connection intensity may affect FF performance in transition economies. In fact, when institutional changes are constant and fast in underdeveloped and government-controlled economic environments, the board political connections become the means for FFs to strengthen their performance in this context.

Finally, our study also offers practical implications for family business owners. It indicates that, in order to strategically overcome the disadvantages related to the relative younger age, lack of legitimacy, and need to reduce resource dependencies, FFs in transition economies may decide to hire nonfamily CEOs who have professional experience and industrial knowledge. That would allow FF owners to focus on the business strategies and prepare for their first succession experience. Alternatively, family owners in the Vietnamese transition economy could capitalize on their family unique advantages by having family leadership combined with boards with multiple politically connected directors. Additionally, this finding also contributes to the debate on professionalization and the role of boards in sustaining family firm performance (Tabor, Chrisman, Madison, \& Vardaman, 2018). Our findings also inform policymakers that they should reconsider the features of the institutional 
ecosystem for organizations, markets, and political systems to promote further the growth of FFs in transition economies.

\section{LIMITATIONS AND FUTURE RESEARCH DIRECTIONS}

This study is not free from limitations that open different avenues for future research. First, although representative of FFs that are listed in Vietnam's stock markets, our sample is not very large. Future research may also collect information on non-listed FFs to gain a more comprehensive picture of this firm type. Second, although this study tests different categories of political connections, such as connections of CEOs, and the political connection intensity of boards of directors, these connections are not sorted into a government-level hierarchy. Future research may need to test the effects of political connections between central governments (for instance, connections to the prime minister or ministers) and local governments (provincial level), as well as across subregions (Li et al., 2012). Indeed, different levels of connections across subregions may lead to different nuances of their impact on firm performance (Zhou, 2013; Banalieva et al., 2015). Third, although political connections have positive effects on performance, such connections are not a "free lunch." There have been concerns about political costs (e.g., political liabilities) and negative effects on firm values and overall economies (e.g., minority shareholders' expropriation, power abuse, and corruption) resulting from political connections (Dinh, \& Calabrò, 2019; Chung, \& Ding, 2010; Sun et al., 2016). Future research could explore what the associated costs are for FFs when they cultivate and seek benefits from political connections and the extent to which marginal benefits outweigh marginal costs. Moreover, this could be done by exploring curvilinear relationships between boards of directors' political connection intensity and firm performance to further explore the existence of possible trade-offs. Nevertheless, this line of research assumes that a board of directors includes nonfamily members; future studies could 
also consider the presence of family members appointed as directors and contributing to board political connection intensity. Fourth, our results also raise ethical questions concerning whether the practice of political connections is "filling" or "abusing" the institutional voids (Luo, \& Chung, 2013). Despite the benefits, political connections might have detrimental effects in the form of "political liability" (Sun et al., 2016; Fan et al., 2007), which negatively affects firms' value and overall economies (e.g., minority shareholders' expropriation, power abuse, and corruption). Therefore, the ethics of establishing political connections by firms, in general, and FFs in particular is open for future debate. Additionally, the majority of Vietnamese FFs are in the first generation but will soon be "passing the baton" to the second generation. Future research may investigate whether political connections still have a critical effect on performance in the second or third generation, and how they are transmitted across generations. Fifth, yet importantly, we urge future research on FFs in emerging economies to dig deeper into the embedded institutional context, especially if this context is simultaneously a transition economy. Despite some similarities, transition economies exhibit different institutional economic characteristics. FFs in this context are characterized by their own idiosyncrasies that are different from "traditional family advantages," which are commonly argued in multi-generation FFs in other institutional environments. Finally, future research may selectively draw from different but related theoretical approach when investigating the role and impact of leadership level on performance, for instance, Upper Echelons theory. This theoretical approach might shed further lights into the rationale behind the composition of top management team and the influence of external industry specific on performance of FFs in transition economies (Yamak, Nielsen, \& Escribá-Esteve, 2014). 


\section{References}

Abegaz, B. (2005) The diversified business group as an innovative organisational model for large state-enterprise reform in China and Vietnam. International Journal of Entrepreneurship and Innovation Management, 5 (5-6), 379-400.

Adhikari, A., Derashid, C. \& Zhang, H. (2006) Public policy, political connections, and effective tax rates: Longitudinal evidence from Malaysia. Journal of Accounting and Public Policy, 25 (5), 574-595.

Adhikari, K.V. \& Le, H.G.G. (2014) Board structure and firm performance in emerging economies: Evidence from Vietnam. Ruhuna Journal of Management and Finance, 1 53-77.

Aguilera, R.V. \& Jackson, G. (2010) Comparative and international corporate governance. The Academy of Management Annals, 4 (1), 485-556.

Aguinis, H., Beaty, J., Boik, R., \& Pierce, C. (2005). Effect Size and Power in Assessing Moderating Effects of Categorical Variables Using Multiple Regression: A 30-Year Review. The Journal of Applied Psychology, 90, 94-107.

Aiken, L S, and S G West. 1991. Multiple Regression: Testing and Interpreting Interactions. Newbury Park, CA: Sage.

Ang, J.S., Ding, D.K. \& Thong, T.Y. (2013) Political Connection and Firm Value. Asian Development Review, 30 (2), 131-166.

Arregle, J.L., Hitt, M.A., Sirmon, D.G. \& Very, P. (2007) The development of organizational social capital: Attributes of family firms. Journal of Management Studies, 44 (1), 73-95.

Baltagi, B.H., Bratberg, E. \& Holmås, T.H. (2005) A panel data study of physicians' labor supply: The case of Norway. Health Economics, 14 (10), 1035-1045.

Baltagi, B.H. \& Wu, P.X. (1999) Unequally spaced panel data regressions with AR (1) disturbances. Econometric Theory, 15 (6), 814-823.

Banalieva, E.R., Eddleston, K.A. \& Zellweger, T.M. (2015) When do family firms have an advantage in transitioning economies? Toward a dynamic institution-based view. Strategic Management Journal, 36 (9), 1358-1377.

Basco, R., Calabrò, A. \& Campopiano, G. (2019) Transgenerational entrepreneurship around the world: Implications for family business research and practice. Journal of Family Business Strategy, 10 (4), 100249.

Bennedsen, M., Fan, J.P.H., Jian, M. \& Yeh, Y.H. (2015) The family business map: Framework, selective survey, and evidence from Chinese family firm succession. Journal of Corporate Finance, 33 212-226.

Berkman, H., Cole, R.A. \& Fu, L.J. (2011) Political connections and minority-shareholder protection: Evidence from securities-market regulation in China. Journal of Financial and Quantitative Analysis, 45 (6), 1391-1417.

Bertrand, M. \& Schoar, A. (2006) The role of family in family firms. The Journal of Economic Perspectives, 20 (2), 73-96.

Boubakri, N., Cosset, J.-C. \& Saffar, W. (2008) Political connections of newly privatized firms. Journal of Corporate Finance, 14 (5), 654-673.

Braendle, U.C., Gasser, T. \& Noll, J. (2005) Corporate governance in China: Is economic growth potential hindered by guanxi? Business and Society Review, 110 (4), 389-405.

Bui, X.H. \& Nunoi, C. (2008) Corporate governance in Vietnam: A system in transition. Hitotsubashi Journal of Commerce and Management, 42 (1 (42), 45-65.

Cai, D., Luo, J.H. \& Wan, D.F. (2012) Family CEOs: Do they benefit firm performance in China? Asia Pacific Journal of Management, 29 (4), 923-947.

Can, V.L. (2017) SMEs development: Vietnamese experience. APEC's Post 2020 Agenda: Rising Protectionism, Economic Rebalancing and Diversified Growth. Singapore.

Cannella Jr, A.A., Jones, C.D. \& Withers, M.C. (2015) Family-versus lone-founder-controlled public corporations: Social identity theory and boards of directors. Academy of Management Journal, 58 (2), 436-459.

Carney, R.W. \& Hamilton-Hart, N. (2015) What do changes in corporate ownership in Indonesia tell us? Bulletin of Indonesian Economic Studies, 51 (1), 123-145. 
Chakrabarty, S. (2009) The influence of national culture and institutional voids on family ownership of large firms: A country level empirical study. Journal of International Management, 15 (1), $32-45$.

Chan, C.M., Makino, S. \& Isobe, T. (2010) Does subnational region matter? Foreign affiliate performance in the United States and China. Strategic Management Journal, 31 (11), 12261243.

Chen, C.J., Li, Z., Su, X. \& Sun, Z. (2011) Rent-seeking incentives, corporate political connections, and the control structure of private firms: Chinese evidence. Journal of Corporate Finance, $17(2), 229-243$.

Chen, V.Z., Li, J. \& Shapiro, D.M. (2011) Are OECD-prescribed "good corporate governance practices" really good in an emerging economy? Asia Pacific Journal of Management, 28 (1), 115-138.

Chen, X.-P. \& Chen, C.C. (2004) On the intricacies of the Chinese guanxi: A process model of guanxi development. Asia Pacific Journal of Management, 21 (3), 305-324.

Chen, Z., Cheung, Y.L., Stouraitis, A. \& Wong, A.W.S. (2005) Ownership concentration, firm performance, and dividend policy in Hong Kong. Pacific-Basin Finance Journal, 13 (4), 431449.

Cheng, M., Lin, B. \& Wei, M. (2015) Executive compensation in family firms: The effect of multiple family members. Journal of Corporate Finance, 32 238-257.

Cheung, Y.-L., Jing, L., Rau, P.R. \& Stouraitis, A. (2005) Guanxi, political connections, and expropriation: The dark side of state ownership in Chinese listed companies. City University of Hong Kong working paper.

Chintagunta, P.K., Jain, D.C. \& Vilcassim, N.J. (1991) Investigating heterogeneity in brand preferences in logit models for panel data. Journal of Marketing Research, 28 (4), 417-428.

Chrisman, J.J. \& Patel, P.C. (2012) Variations in R\&D investments of family and nonfamily firms: Behavioral agency and myopic loss aversion perspectives. Academy of Management Journal, 55 (4), 976-997.

Chu, W. (2009) The influence of family ownership on SME performance: Evidence from public firms in Taiwan. Small Business Economics, 33 (3), 353-373.

Chua, J.H., Chrisman, J.J., Steier, L.P. \& Rau, S.B. (2012) Sources of heterogeneity in family firms: An introduction. Entrepreneurship Theory and Practice, 36 (6), 1103-1113.

Chung, H.M. \& Ding, H.B. (2010) Political connections and family business diversification. Advances in Mergers and Acquisitions, 9135.

Dana, L.-P. \& Ramadani, V. (2015) Family businesses in transition economies, Switzerland: Springer International Publishing Switzerland.

Dang, H. \& Vo, V.Q. (2019) History of Family Businesses in Vietnam (Lịch sử các thương hiệu gia tộc kinh doanh Việt Nam). The Leader. Hanoi: The Business Leaders Forum of Vietnam Association of Corporate Directors (VACD).

Desender, K.A., Aguilera, R.V., Lópezpuertas-Lamy, M. \& Crespi, R. (2016) A clash of governance logics: Foreign ownership and board monitoring. Strategic Management Journal, 37 (2), 349369.

Dinh, T.Q. \& Calabrò, A. (2019) Asian family firms through corporate governance and institutions: A systematic review of the literature and agenda for future research. International Journal of Management Reviews, 21 (1), 50-75.

Dinh, T.Q. \& Hilmarsson, H.P. (2020) Understanding" Guanxi" in the Asian business context. Review of International Comparative Management, 21 (1), 12-22.

Do, X.Q. \& Wu, Z.X. (2014) The impact of ownership structure and capital structure on financial performance of Vietnamese firms. International Business Research, 7 (2), 64.

Dou, J. \& Li, S. (2013) The succession process in Chinese family firms: A guanxi perspective. Asia Pacific Journal of Management, 30 (3), 893-917.

Drukker, D.M. (2003) Testing for serial correlation in linear panel-data models. The Stata Journal, 3 (2), 168-177.

Faccio, M. (2006) Politically connected firms. The American Economic Review, 96 (1), 369-386.

Faccio, M., Masulis, R.W. \& McConnell, J. (2006) Political connections and corporate bailouts. The Journal of Finance, 61 (6), 2597-2635. 
Fan, J.P., Wei, K.J. \& Xu, X. (2011) Corporate finance and governance in emerging markets: A selective review and an agenda for future research. Journal of Corporate Finance, 17 (2), 207-214.

Fan, J.P., Wong, T.J. \& Zhang, T. (2007) Politically connected CEOs, corporate governance, and Post-IPO performance of China's newly partially privatized firms. Journal of Financial Economics, 84 (2), 330-357.

Filatotchev, I., Jackson, G. \& Nakajima, C. (2013) Corporate governance and national institutions: A review and emerging research agenda. Asia Pacific Journal of Management, 30 (4), 965-986.

Finkelstein, S., Cannella, S.F.B., Hambrick, D.C. \& Cannella, A.A. (2009) Strategic leadership: Theory and research on executives, top management teams, and boards: Oxford University Press, USA.

Ge, J., Carney, M. \& Kellermanns, F. (2018) Who fills institutional voids? Entrepreneurs' utilization of political and family ties in emerging markets. Entrepreneurship Theory and Practice, 43 (6), 1124-1147.

Gedajlovic, E., Carney, M., Chrisman, J.J. \& Kellermanns, F.W. (2012) The adolescence of family firm research: Taking stock and planning for the future. Journal of Management, 38 (4), 1010-1037.

Gettleman ME, Franklin J, Young MB, et al. (1995) Vietnam and America: a documented history: Grove Press.

Gomez-Mejia, L., R., Basco, R., Müller, C. \& Gonzalez, A.C. (2020) Family business and local development in Iberoamerica. Cross-Cultural Management Journal, Forthcoming.

GSO. (2005) General Statistics Office. Statistical yearbook 2004. Hanoi: Statistics Publishing House.

Guriev, S. (2004) Red tape and corruption. Journal of Development Economics, 73 (2), 489-504.

Hakkala, K. \& Kokko, A. (2007) The state and the private sector in Vietnam. Working Paper. The European Institute of Japanese Studies. In: Studies TEIoJ (ed).

Hammond, N.L., Pearson, A.W. \& Holt, D.T. (2016) The quagmire of legacy in family firms: Definition and implications of family and family firm legacy orientations. Entrepreneurship Theory and Practice, 40 (6), 1209-1231.

Hillman, A.J. (2005) Politicians on the Board of Directors: Do connections affect the bottom line? Journal of Management, 31 (3), 464-481.

Hillman, A.J. \& Dalziel, T. (2003) Boards of directors and firm performance: Integrating agency and resource dependence perspectives. Academy of Management Review, 28 (3), 383-396.

Hillman, A.J., Withers, M.C. \& Collins, B.J. (2009) Resource dependence theory: A review. Journal of management, 35 (6), 1404-1427.

HoSE. (2014) Annual Report 2014. Ho Chi Minh City: Ho Chi Minh Stock Market.

Hoskisson, R.E., Eden, L., Lau, C.M. \& Wright, M. (2000) Strategy in emerging economies. Academy of Management Journal, 43 (3), 249-267.

Houston, J.F., Jiang, L., Lin, C. \& Ma, Y. (2014) Political connections and the cost of bank loans. Journal of Accounting Research, 52 (1), 193-243.

James, A., Hadjielias, E., Guerrero, M., Discua Cruz, A. \& Basco, R. (2020) Entrepreneurial families in business across generations, contexts, and cultures. Journal of Family Business Management, forthcoming.

Jensen, M. \& Zajac, E.J. (2004) Corporate elites and corporate strategy: How demographic preferences and structural position shape the scope of the firm. Strategic Management Journal, 25 (6), 507-524.

Jiang, Y. \& Peng, M.W. (2011) Are family ownership and control in large firms good, bad, or irrelevant? Asia Pacific Journal of Management, 28 (1), 15-39.

Joh, S.W. (2003) Corporate governance and firm profitability: Evidence from Korea before the economic crisis. Journal of Financial Economics, 68 (2), 287-322.

Johnson, R.A., Schnatterly, K., Johnson, S.G. \& Chiu, S.C. (2010) Institutional investors and institutional environment: A comparative analysis and review. Journal of Management Studies, 47 (8), 1590-1613.

Johnson, S., Kaufmann, D., McMillan, J. \& Woodruff, C. (2000) Why do firms hide? Bribes and unofficial activity after communism. Journal of Public Economics, 76 (3), 495-520. 
Khanna, T. \& Palepu, K. (1997) Why focused strategies may be wrong for emerging markets. Harvard Business Review, 75 (4), 41-48.

Le Minh, T. \& Walker, G. (2008) Corporate governance of listed companies in Vietnam. Bond Law Review, 20 (2 (6)), 1-80.

Le, N.T. \& Nguyen, T.V. (2009) The impact of networking on bank financing: the case of small and medium-sized enterprises in Vietnam. Entrepreneurship Theory and Practice, 33 (4), $867-$ 887.

Lester, R.H. \& Cannella, A.A. (2006) Interorganizational familiness: How family firms use interlocking directorates to build community-level social capital. Entrepreneurship Theory and Practice, 30 (6), 755-775.

Leuz, C. \& Oberholzer-Gee, F. (2006) Political relationships, global financing, and corporate transparency: Evidence from Indonesia. Journal of Financial Economics, 81 (2), 411-439.

Li, H., Meng, L., Wang, Q. \& Zhou, L.A. (2008) Political connections, financing and firm performance: Evidence from Chinese private firms. Journal of development economics, 87 (2), 283-299.

Li, H. \& Zhang, Y. (2007) The role of managers' political networking and functional experience in new venture performance: Evidence from China's transition economy. Strategic Management Journal, 28 (8), 791-804.

Li, H. \& Zhou, L.-A. (2005) Political turnover and economic performance: the incentive role of personnel control in China. Journal of Public Economics, 89 (9), 1743-1762.

Li, W., He, A., Lan, H. \& Yiu, D. (2012) Political connections and corporate diversification in emerging economies: Evidence from China. Asia Pacific Journal of Management, 29 (3), 799-818.

Liu, Q., Luo, T. \& Tian, G.G. (2015) Family control and corporate cash holdings: Evidence from China. Journal of Corporate Finance, 31 220-245.

Loc, T.D., Lanjouw, G. \& Lensink, R. (2006) The impact of privatization on firm performance in a transition economy: The case of Vietnam 1. Economics of Transition, 14 (2), 349-389.

Luo, X. \& Chung, C.-N. (2005) Keeping it all in the family: The role of particularistic relationships in business group performance during institutional transition. Administrative Science Quarterly, $50(3), 404-439$.

Luo, X., Chung, C.N. \& Sobczak, M. (2009) How do corporate governance model differences affect foreign direct investment in emerging economies? Journal of International Business Studies, 40 (3), 444-467.

Luo, X.R. \& Chung, C.N. (2013) Filling or abusing the institutional void? Ownership and management control of public family businesses in an emerging market. Organization Science, 24 (2), 591-613.

Luong, V.H. \& Diep, D.H. (1991) Culture and capitalism in the pottery enterprises of Bien Hoa, South Vietnam (1878-1975). Journal of Southeast Asian Studies, 22 (1), 16-32.

Manikutty, S. (2000) Family business groups in India: A resource-based view of the emerging trends. Family Business Review, 13 (4), 279-292.

Mazzi, C. (2011) Family business and financial performance: Current state of knowledge and future research challenges. Journal of Family Business Strategy, 2 (3), 166-181.

McMillan, J. \& Woodruff, C. (2002) The central role of entrepreneurs in transition economies. Journal of Economic Perspectives, 16 (3), 153-170.

Miller, D. \& Breton-Miller, L. (2006) Family governance and firm performance: Agency, stewardship, and capabilities. Family Business Review, 19 (1), 73-87.

Miller, D., Lee, J., Chang, S. \& Breton-Miller, I.L. (2009) Filling the institutional void: The social behavior and performance of family vs non-family technology firms in emerging markets. Journal of International Business Studies, 40 (5), 802-817.

Min, B.S. (2013) Evaluation of board reforms: An examination of the appointment of outside directors. Journal of the Japanese and International Economies, 29 (0), 21-43.

Morck, R. \& Yeung, B. (2004) Family control and the rent-seeking society. Entrepreneurship Theory and Practice, 28 (4), 391-409.

Netter, J.W. \& Knut, M.H. (1990) Applied linear statistical models: Regression, analysis of variance, and exprimental design. Homewood: IL: Irwin. 
Nguyen, T.T. \& Van Dijk, M.A. (2012) Corruption, growth, and governance: Private vs. state-owned firms in Vietnam. Journal of Banking \& Finance, 36 (11), 2935-2948.

Opper, S. (2008) $18 \mathrm{New}$ institutional economics and its application on transition and developing economies. In: Brousseau E and Glachant J-M (eds) New institutional economics - A guidebook. Cambridge: Cambridge University Press, 389.

Ovaska, T. \& Sobel, R.S. (2005) Entrepreneurship in post-socialist economies. Journal of Private Enterprise, 21 (1), 8-28.

Peng, M.W. (2004) Outside directors and firm performance during institutional transitions. Strategic Management Journal, 25 (5), 453-471.

Peng, M.W. \& Jiang, Y. (2010) Institutions behind family ownership and control in large firms. Journal of Management Studies, 47 (2), 253-273.

Peng, M.W. \& Luo, Y. (2000) Managerial ties and firm performance in a transition economy: The nature of a micro-macro link. Academy of Management Journal, 43 (3), 486-501.

Pfeffer, J. \& Salancik, G. (1978) The external control of companies: A resource dependence perspective. Harper \& Row, New York, NY.

Pfeffer, J. \& Salancik, G.R. (2003) The external control of organizations: A resource dependence perspective: Stanford University Press.

Phung, D.N. \& Hoang, T.P.T. (2013) Corporate Ownership and Firm Performance in Emerging Market: A Study of Vietnamese Listed Firms. World Business and Social Science Research Conference. Bangkok October 2013, 15.

Prabowo, M. \& Simpson, J. (2011) Independent directors and firm performance in family controlled firms: evidence from Indonesia. Asian-Pacific Economic Literature, 25 (1), 121-132.

Qian, M., Pan, H. \& Yeung, B. (2011) Expropriation of minority shareholders in politically connected firms. Unpublished working paper. The National University of Singapore.

Robinett, D., Benedetta, P.D. \& Nguyet Anh, A. (2013) Report on the Observance of Standards and Codes (ROSC): Corporate governance country assessment. . Washington, DC: World Bank Group.

Rutherford, M.W. \& Kuratko, D.F. (2016) Toward the validation of family legacy orientation. Entrepreneurship Theory and Practice, 40 (6), 1233-1239.

Salvato, C. \& Melin, L. (2008) Creating value across generations in family-controlled businesses: The role of family social capital. Family Business Review, 21 (3), 259-276.

Schumpeter. (2011) Family capitalism - All in the family. Special Report. The Economist.

Sensoy, A., Ozturk, K., Hacihasanoglu, E. \& Tabak, B.M. (2017) Not all emerging markets are the same: A classification approach with correlation based networks. Journal of Financial Stability, 33 163-186.

Sharif, S.P., Kyid, Y.K. \& Wei, K.K. (2015) The acquisition of valuable resources by family controlled companies in Malaysia through political connections of their independent directors. Journal of Developing Areas, 49 (5), 309-319.

Shi, W., Markóczy, L. \& Stan, C.V. (2014) The continuing importance of political ties in China. Academy of Management Perspectives, 28 (1), 57-75.

Shleifer, A. (1998) State versus private ownership. Journal of Economic Perspectives, 12 (4), 133150.

Singal, M. \& Singal, V. (2011) Concentrated ownership and firm performance: Does family control matter? Strategic Entrepreneurship Journal, 5 (4), 373-396.

Sirmon, D.G., Arregle, J.L., Hitt, M.A. \& Webb, J.W. (2008) The role of family influence in firms' strategic responses to threat of imitation. Entrepreneurship Theory and Practice, 32 (6), 979998.

Sjöholm, F. (2006) State owned enterprises and equitization in Vietnam, Stockholm: European Institute of Japanese Studies.

Solomon, J.F., Lin, S.W., Norton, S.D. \& Solomon, A. (2003) Corporate governance in Taiwan: Empirical evidence from Taiwanese company directors. Corporate Governance: An International Review, 11 (3), 235-248.

Steier, L.P. (2009) Familial capitalism in global institutional contexts: Implications for corporate governance and entrepreneurship in East Asia. Asia Pacific Journal of Management, 26 (3), 513. 
Su, Y., Xu, D. \& Phan, P.H. (2008) Principal-principal conflict in the governance of the Chinese public corporation. Management and Organization Review, 4 (1), 17-38.

Sun, P., Hu, H.W. \& Hillman, A.J. (2016) The dark side of board political capital: Enabling blockholder rent appropriation. Academy of Management Journal, 59 (5), 1801-1822.

Tabor, W., Chrisman, J.J., Madison, K. \& Vardaman, J.M. (2018) Nonfamily members in family firms: A review and future research agenda. Family Business Review, 31 (1), 54-79.

Tang, Y., Ye, S. \& Zhou, J. (2013) Political connections, legal environment, and corporate valuation in Chinese public family firms. The Chinese Economy, 46 (6), 32-49.

Tran, N.M., Nonneman, W. \& Jorissen, A. (2015) Privatization of Vietnamese firms and its effects on firm performance. Asian Economic and Financial Review, 5 (2), 202.

Tran, Q., Koufopoulos, D.N. \& Warner, B. (2014) The effectiveness of boards of directors in two-tier board system: Evidence from Vietnamese-listed enterprises'. Journal of Eastern European and Central Asian Research, 1 (1), 58-65.

Tsai, W.-C., Wang, W.-Y., Ho, P.-H. \& Lin, C.-Y. (2016) Bank loan supply in the financial crisis: Evidence from the role of political connection. Emerging Markets Finance and Trade, 52 (2), 487-497.

Viet, H.N. (2015) Succession decision in Vietnamese family companies. International Journal of Business and Management, 10 (7), 208.

Vo, T.Q., Swierczek, F.W. \& Nguyen, D.K. (2013) Corporate performance of privatized firms in Vietnam. Journal of Applied Business Research (JABR), 29 (5), 1437-1450.

Wang, D., Ma, G., Song, X. \& Liu, Y. (2016) Political connection and business transformation in family firms: Evidence from China. Journal of Family Business Strategy, 7 (2), 117-130.

Williamson, O.E. (1996) The mechanisms of governance: Oxford University Press.

Williamson, O.E. (2000) The new institutional economics: Taking stock, looking ahead. Journal of Economic Literature, 38 (3), 595-613.

Williamson, O.E., Brousseau, E. \& Glachant, J. (2008) New Institutional Economics, A Guidebook, London, UK: Cambrige University Press.

Wooldridge, J.M. (2002) Inverse probability weighted M-estimators for sample selection, attrition, and stratification. Portuguese Economic Journal, 1 (2), 117-139.

Wu, W., Wu, C. \& Rui, O.M. (2010) Ownership and the value of political connections: Evidence from China. European Financial Management, 18 (4), 695-729.

Wu, W., Wu, C., Zhou, C. \& Wu, J. (2012) Political connections, tax benefits and firm performance: Evidence from China. Journal of Accounting and Public Policy, 31 (3), 277-300.

Xin, K.K. \& Pearce, J.L. (1996) Guanxi: Connections as substitutes for formal institutional support. Academy of Management Journal, 39 (6), 1641-1658.

Xu, D. \& Meyer, K.E. (2013) Linking theory and context:'Strategy research in emerging economies' after Wright et al.(2005). Journal of Management Studies, 50 (7), 1322-1346.

Xu, N., Xu, X. \& Yuan, Q. (2013) Political connections, financing friction, and corporate investment: Evidence from Chinese listed family firms. European Financial Management, 19 (4), 675702.

Xu, N., Yuan, Q., Jiang, X. \& Chan, K.C. (2015) Founder's political connections, second generation involvement, and family firm performance: Evidence from China. Journal of Corporate Finance, 33 243-259.

Yamak, S., Nielsen, S., \& Escribá-Esteve, A. (2014). The role of external environment in upper echelons theory: A review of existing literature and future research directions. Group \& Organization Management, 39(1), 69-109.

Yiu, D., Bruton, G.D. \& Lu, Y. (2005) Understanding business group performance in an emerging economy: Acquiring resources and capabilities in order to prosper. Journal of Management Studies, 42 (1), 183-206.

Yoshikawa, T. \& Rasheed, A.A. (2010) Family control and ownership monitoring in familycontrolled firms in Japan. Journal of Management Studies, 47 (2), 274-295.

You, J. \& Du, G. (2012) Are political connections a blessing or a curse? Evidence from CEO turnover in China. Corporate Governance: An International Review, 20 (2), 179-194. 
Young, C.S. \& Tsai, L.C. (2008) The sensitivity of compensation to social capital: Family CEOs vs. nonfamily CEOs in the family business groups. Journal of Business Research, 61 (4), 363374.

Young, M.N., Peng, M.W., Ahlstrom, D., Bruton, G.D. \& Jiang, Y. (2008) Corporate governance in emerging economies: A review of the principal-principal perspective. Journal of Management Studies, 45 (1), 196-220.

Zahra, S.A., Hayton, J.C., Neubaum, D.O., Dibrell, C. \& Craig, J. (2008) Culture of family commitment and strategic flexibility: The moderating effect of stewardship. Entrepreneurship Theory and Practice, 32 (6), 1035-1054.

Zheng, W., Singh, K. \& Chung, C.-N. (2017) Ties to unbind: Political ties and firm sell-offs during institutional transition. Journal of Management, 43 (7), 2005-2036.

Zhou, W. (2013) Political connections and entrepreneurial investment: Evidence from China's transition economy. Journal of Business Venturing, 28 (2), 299-315. 


\section{FIGURES AND TABLES}

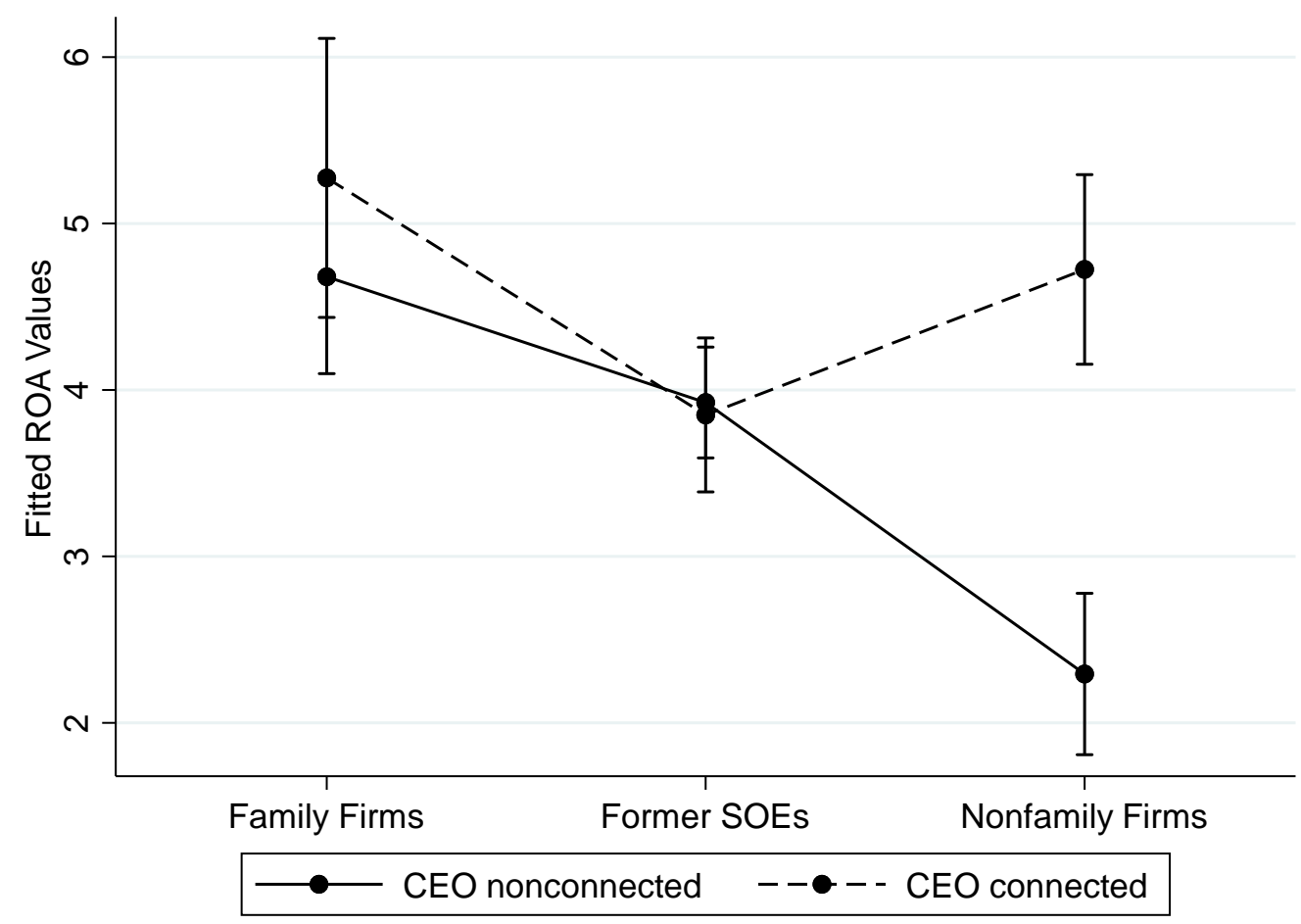

Figure 1: The moderation effect of CEO political connection on the relationship between type of firms and firm performance (predictive margins with $95 \% \mathrm{CIs}$ ). 


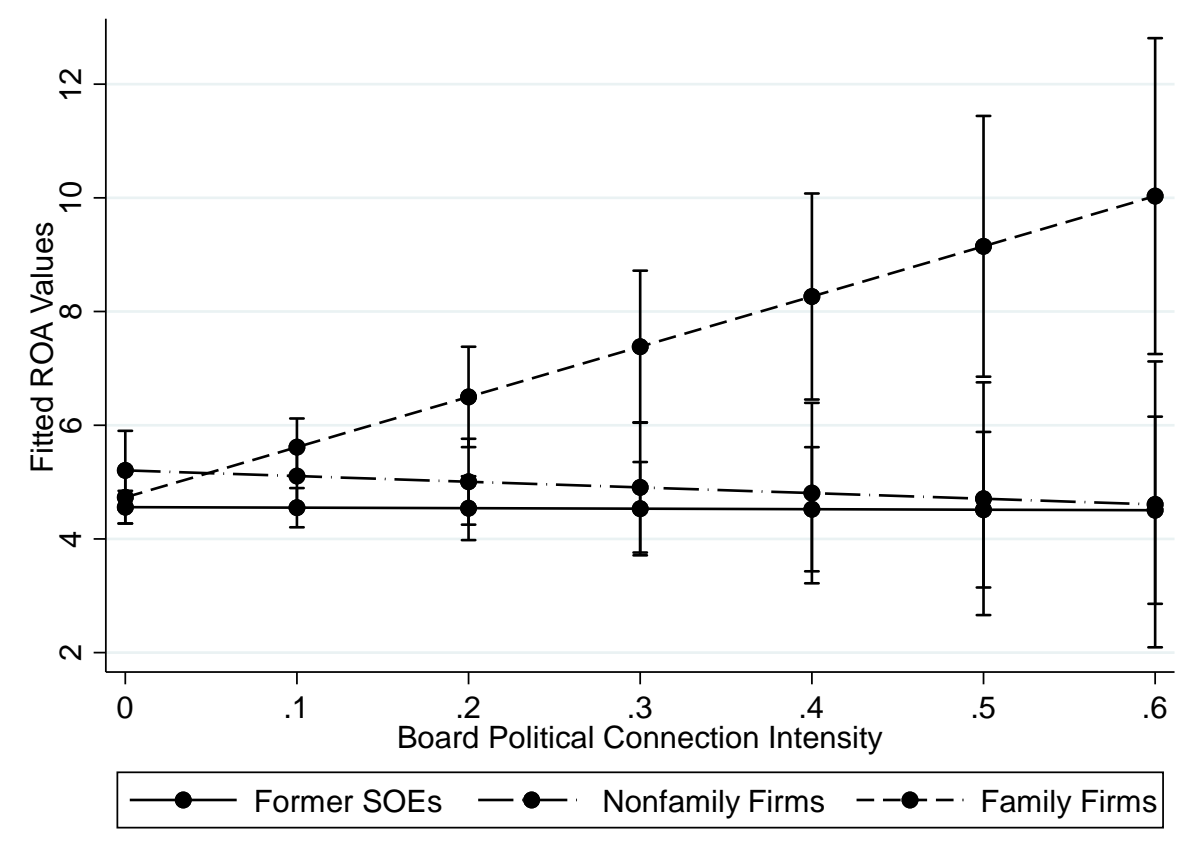

Figure 2: The moderation effect of board political connection on the relationship between type of firms and firm performance (predictive margins with 95\% CIs).

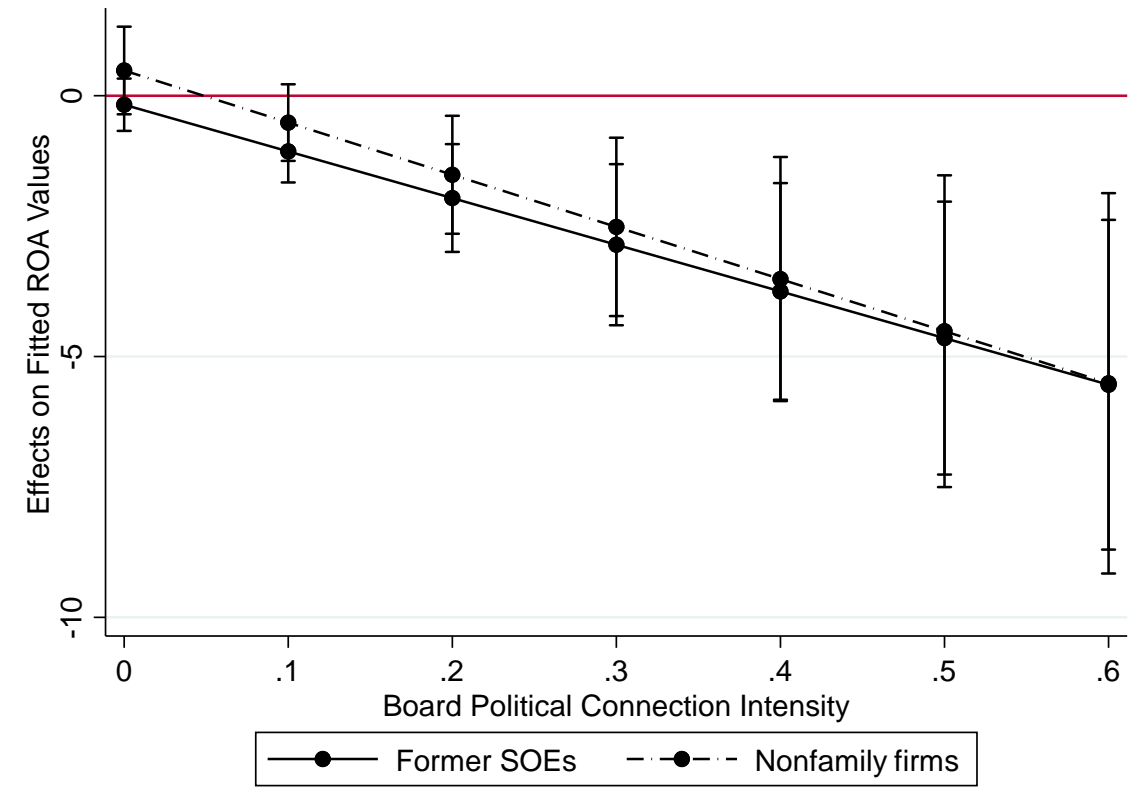

Figure 3: Conditional marginal effect: family firms vs. nonfamily firms and family firms vs. former SOEs, differences at alternative level of board political connection intensity. 


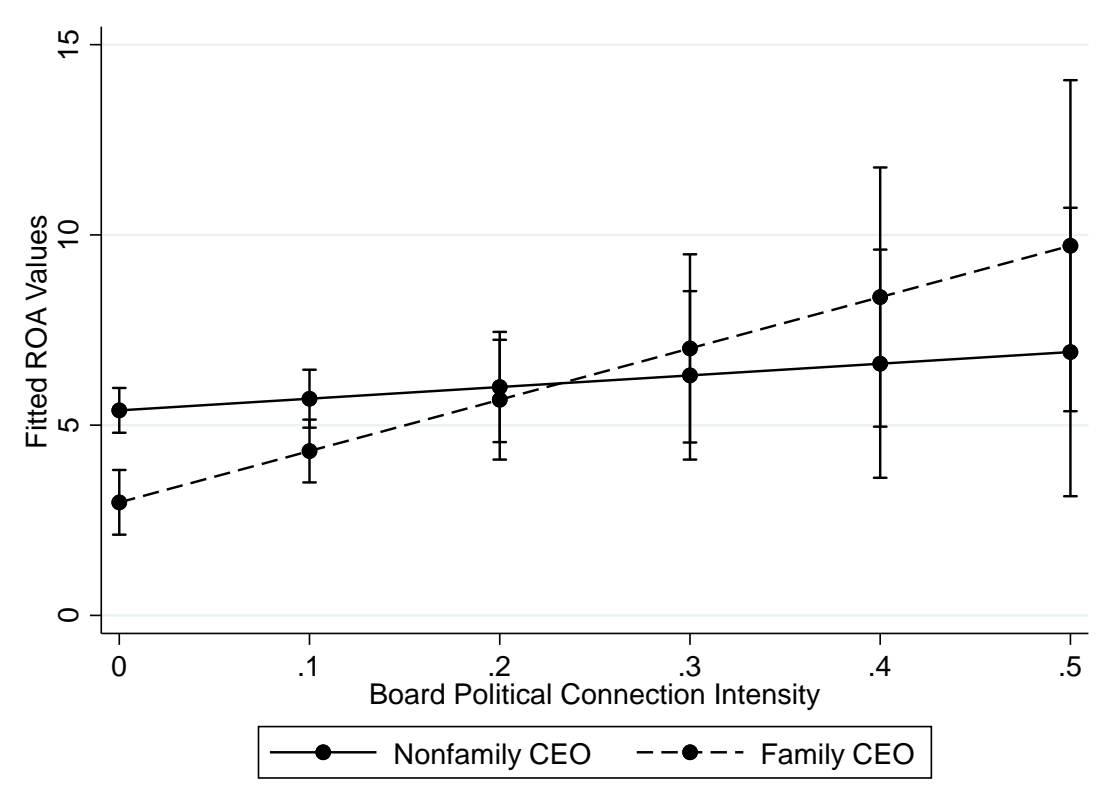

Figure 4: The moderator effect of board political connection on the relationship between family CEO and firm performance (predictive margins with 95\% CIs).

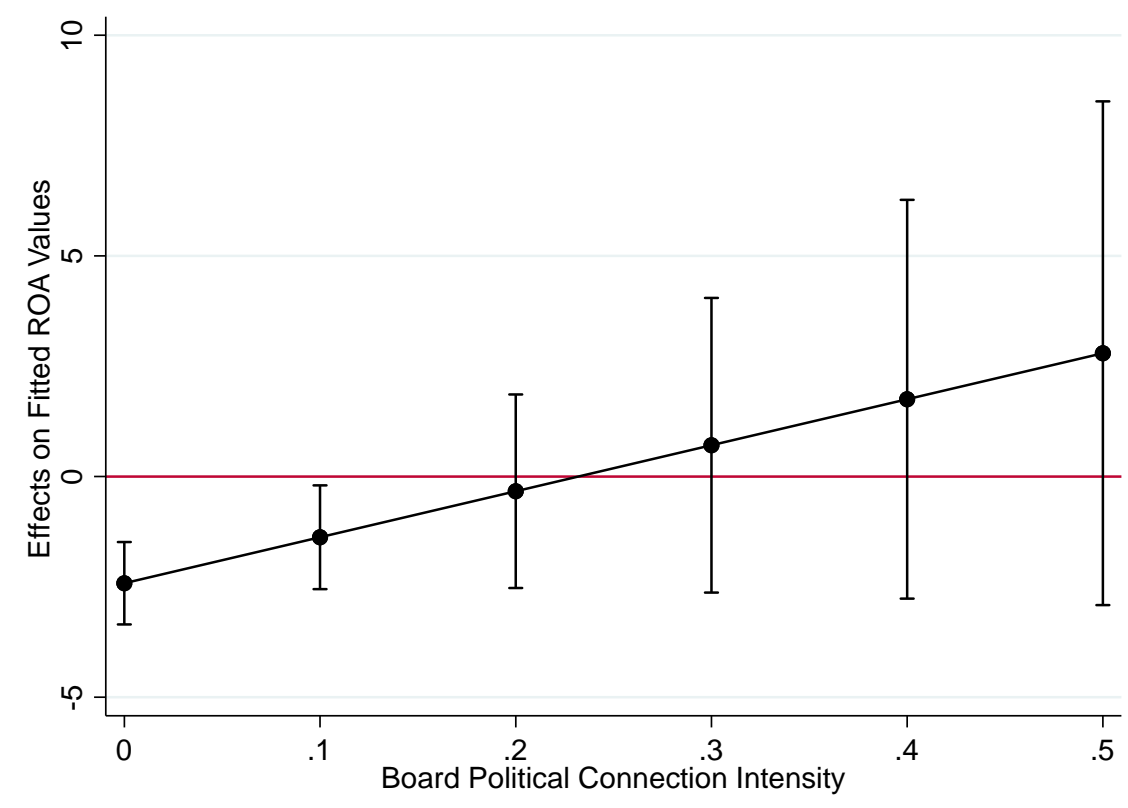

Figure 5: Conditional marginal effect: family CEO vs. nonfamily CEO, differences at alternative level of board political connection intensity. 
Table 1: Description of variables

\begin{tabular}{ll}
\hline \multicolumn{1}{c}{ Indicator } & \multicolumn{1}{c}{ Description } \\
\hline ROA & Return on assets: net income $/$ total assets \\
Types_of_firms & Categorical variable: family firms $=1$, former SOEs $=2$, nonfamily firm $=3$ \\
Family_firm & Dummy variable: family firms $=1$, otherwise $=0$ \\
Former_SOE & Dummy variable: former SOEs $=1$, otherwise $=0$ \\
Nonfamily_firm & Dummy variable: nonfamily firm $=1$, otherwise $=0$ \\
Family_CEO & Dummy variable: CEO is family member $=1$, CEO is not family member $=0$ \\
\% Family_Ownership & $\%$ of shares held by family members \\
CEO_Connected & Dummy variable: CEO is politically connected $=1$, otherwise $=0$ \\
Board_Political_Connection_Intenisty & $\begin{array}{l}\text { Ratio of total of politically connected directors and board size (in case of CEO duality, } \\
\text { the CEO was removed from both numerator and denominator }\end{array}$ \\
CEO_Duality & Dummy variable: CEO duality $=1$, otherwise $=0$ \\
CEO_Age & CEO age \\
Board_Size (ln) & Log of total number of board members \\
Firm_Age & Log of firm age (years since establishment) \\
Firm_Size & Log of total assets \\
Firm_Leverage & Total debts / total assets \\
Year & Dummy variables \\
Industry & $\begin{array}{l}\text { Dummy variables (categorized according to North American Industry Classification } \\
\text { System (NAICS) 2007) }\end{array}$ \\
\hline
\end{tabular}


Table 2a: Descriptive statistics and correlations (whole sample $\mathrm{N}=1835$ )

\begin{tabular}{|c|c|c|c|c|c|c|c|c|c|c|c|c|c|c|c|}
\hline & Mean & sd & Min. & Max. & 1 & 2 & 3 & 4 & 5 & 6 & 7 & 8 & 9 & 10 & 11 \\
\hline 1. ROA & 5.08 & 5.72 & -13.74 & 20.43 & & & & & & & & & & & \\
\hline 2. Firm_Leverage & 0.51 & 0.53 & 0.00 & 16.90 & 0.00989 & & & & & & & & & & \\
\hline 3. Firm_Size (ln) & 27.21 & 1.60 & 23.13 & 33.29 & $0.0870^{* * * *}$ & $0.0703^{* * *}$ & & & & & & & & & \\
\hline 4. Fim_Age $(\ln )$ & 3.03 & 0.57 & 0.69 & 4.14 & 0.0223 & -0.0193 & -0.0345 & & & & & & & & \\
\hline 5. Board Size (ln) & 1.90 & 0.27 & 1.10 & 2.40 & $0.145^{* * * *}$ & -0.0261 & $0.0857^{* * * *}$ & $-0.136^{* * *}$ & & & & & & & \\
\hline 6. CEO_Duality & 0.42 & 0.49 & 0 & 1 & -0.0252 & 0.0136 & $\overline{-}^{-}$ & $-0.0585^{*}$ & -0.00660 & & & & & & \\
\hline 7. CEO_Age & 49.20 & 8.36 & 24 & 75 & 0.00404 & $\begin{array}{c}- \\
0.0894^{* * *}\end{array}$ & 0.0351 & $0.207^{* * *}$ & $-0.0596^{*}$ & $0.193^{* * *}$ & & & & & \\
\hline 8. FFs & 0.30 & .46 & 0 & 1 & $0.0938^{* * *}$ & 0.00696 & $0.267^{* * *}$ & $-0.108^{* * *}$ & -0.00121 & $0.111^{* * *}$ & $-0.0710^{* *}$ & & & & \\
\hline 9. Former SOEs & 0.19 & .39 & 0 & 1 & -0.00784 & -0.0379 & $-0.129^{* * * *}$ & $0.106^{* * *}$ & $-0.0471^{*}$ & -0.0244 & 0.00611 & $-0.318^{* * *}$ & & & \\
\hline 10. Non-FFs & 0.51 & .50 & 0 & 1 & $\overline{-}^{-0799^{* * * *}}$ & 0.0233 & $-0.144^{* * *}$ & 0.0157 & 0.0381 & $0.0828^{* * *}$ & $0.0603^{* * *}$ & $-0.668^{* * * *}$ & $-0.493^{* * *}$ & & \\
\hline 11. Board_Political_Connection_Intensity & 0.04 & 0.08 & 0 & 0.6 & $0.0474^{*}$ & -0.00192 & $0.121^{* * *}$ & $-0.0505^{*}$ & -0.0147 & $\begin{array}{l}0.0020 \text { 作 } \\
-0.412^{* * *}\end{array}$ & -0.0416 & -0.0269 & $0.190^{* * * *}$ & $-0.124^{* * *}$ & \\
\hline 12. CEO_Connected & 0.46 & 0.50 & 0 & 1 & $0.0907^{* * *}$ & 0.00115 & $0.0852^{* * *}$ & $0.247^{* * * *}$ & -0.00245 & $0.0826^{* * *}$ & $0.174^{* * * *}$ & $-0.107^{* * * *}$ & $0.283^{* * *}$ & $-0.124^{* * * *}$ & $0.0906^{* * *}$ \\
\hline
\end{tabular}


Table 2b: Descriptive statistics and correlations (family firm sample $\mathrm{N}=460$ )

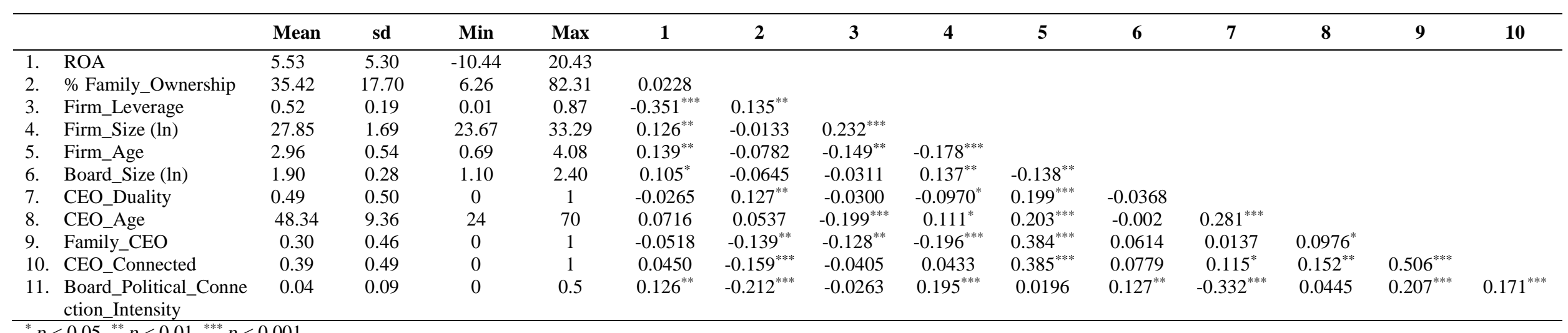


Table 3: FGLS regression results - types of firms and political connections (overall sample)

\begin{tabular}{|c|c|c|c|c|}
\hline & $\begin{array}{c}\text { Model } 1 \\
\text { ROA }\end{array}$ & $\begin{array}{c}\text { Model } 2 \\
\text { ROA }\end{array}$ & $\begin{array}{c}\text { Model } 3 \\
\text { ROA }\end{array}$ & $\begin{array}{c}\text { Model } 4 \\
\text { ROA }\end{array}$ \\
\hline Firm_Leverage & $\begin{array}{c}-2.236 * * * \\
(0.365)\end{array}$ & $\begin{array}{c}-2.302 * * * \\
(0.341)\end{array}$ & $\begin{array}{c}-2.273 * * * \\
(0.341)\end{array}$ & $\begin{array}{c}-2.295 * * * \\
(0.342)\end{array}$ \\
\hline Firm_Size (ln) & $\begin{array}{l}0.160 * \\
(0.077)\end{array}$ & $\begin{array}{l}-0.014 \\
(0.076)\end{array}$ & $\begin{array}{c}0.044 \\
(0.074)\end{array}$ & $\begin{array}{c}-0.001 \\
(0.074)\end{array}$ \\
\hline Firm Age (ln) & $\begin{array}{l}0.446^{*} \\
(0.196)\end{array}$ & $\begin{array}{l}0.491^{*} \\
(0.197)\end{array}$ & $\begin{array}{l}0.415^{*} \\
(0.194)\end{array}$ & $\begin{array}{l}0.482^{*} \\
(0.192)\end{array}$ \\
\hline Board_Size (ln) & $\begin{array}{c}0.265 \\
(0.303)\end{array}$ & $\begin{array}{l}0.640^{*} \\
(0.317)\end{array}$ & $\begin{array}{l}0.694 * \\
(0.313)\end{array}$ & $\begin{array}{l}0.570+ \\
(0.316)\end{array}$ \\
\hline CEO_Duality & $\begin{array}{c}-0.973 * * * \\
(0.181)\end{array}$ & $\begin{array}{c}-0.901 * * * * \\
(0.198)\end{array}$ & $\begin{array}{c}-0.898 * * * \\
(0.196)\end{array}$ & $\begin{array}{c}-0.823 * * * \\
(0.196)\end{array}$ \\
\hline CEO_Age & $\begin{array}{l}0.027^{*} \\
(0.012)\end{array}$ & $\begin{array}{l}0.030^{*} \\
(0.012)\end{array}$ & $\begin{array}{c}0.034 * * \\
(0.012)\end{array}$ & $\begin{array}{l}0.024^{*} \\
(0.012)\end{array}$ \\
\hline \multicolumn{5}{|l|}{ (Family Firms as reference group) } \\
\hline Non-FFs & & $\begin{array}{c}-0.898^{*} \\
(0.378)\end{array}$ & & $\begin{array}{l}-0.238 \\
(0.448)\end{array}$ \\
\hline Former SOEs & & $\begin{array}{c}-1.013 * * * \\
(0.271)\end{array}$ & & $\begin{array}{l}-0.594 * \\
(0.276)\end{array}$ \\
\hline CEO_Connected & & $\begin{array}{l}0.422+ \\
(0.255)\end{array}$ & & $\begin{array}{l}0.477^{*} \\
(0.243)\end{array}$ \\
\hline Board_Political_Connection_Intensity & & $\begin{array}{l}2.573^{*} \\
(1.081)\end{array}$ & $\begin{array}{c}3.072 * * \\
(0.981)\end{array}$ & $\begin{array}{c}9.778 * * * \\
(2.931)\end{array}$ \\
\hline \multicolumn{5}{|l|}{ (Family Firms $*$ CEO_Connected as reference group) } \\
\hline Non-FFs * CEO_Connected & & & $\begin{array}{c}-0.550 \\
(0.524)\end{array}$ & \\
\hline Non-FFs $*$ CEO_Nonconnected & & & $\begin{array}{c}-2.980 * * * \\
(0.497)\end{array}$ & \\
\hline Former SOEs * CEO_Connected & & & $\begin{array}{c}-1.424 * * \\
(0.488)\end{array}$ & \\
\hline Former SOEs * CEO_Nonconnected & & & $\begin{array}{c}-1.350 * * \\
(0.459)\end{array}$ & \\
\hline Family Firms * CEO_Nonconnected & & & $\begin{array}{c}-0.594 \\
(0.520)\end{array}$ & \\
\hline Non-FFs * Board_Political_Connection_Intensity & & & & $\begin{array}{c}-10.540 * * \\
(3.722)\end{array}$ \\
\hline Former SOEs * Board_Political_Connection_Intensity & & & & $\begin{array}{c}-9.851^{* *} \\
(3.199)\end{array}$ \\
\hline _cons & $\begin{array}{c}1.852 \\
(2.269)\end{array}$ & $\begin{array}{l}5.566^{*} \\
(2.379)\end{array}$ & $\begin{array}{l}4.554+ \\
(2.333)\end{array}$ & $\begin{array}{l}5.082^{*} \\
(2.349)\end{array}$ \\
\hline Year fixed effects & Yes & Yes & Yes & Yes \\
\hline Industry fixed effects & Yes & Yes & Yes & Yes \\
\hline Wald Chi 2 & 458.27 & 645.84 & 582.00 & 669.50 \\
\hline Observations & 1649 & 1649 & 1649 & 1649 \\
\hline Number of ID & 200 & 200 & 200 & 200 \\
\hline
\end{tabular}

Standard errors in parentheses

$+p<0.10, * p<0.05, * * p<0.01, * * * p<0.001$ 
Table 4: FGLS regression results for family CEO and political connections (family firm sample)

\begin{tabular}{|c|c|c|c|c|}
\hline & $\begin{array}{c}\text { Model } 1 \\
\text { ROA }\end{array}$ & $\begin{array}{c}\text { Model } 2 \\
\text { ROA }\end{array}$ & $\begin{array}{c}\text { Model } 3 \\
\text { ROA }\end{array}$ & $\begin{array}{c}\text { Model } 4 \\
\text { ROA }\end{array}$ \\
\hline \% Family_Ownership & $\begin{array}{l}-0.009 \\
(-0.76)\end{array}$ & $\begin{array}{c}0.002 \\
(0.23)\end{array}$ & $\begin{array}{l}-0.002 \\
(-0.17)\end{array}$ & $\begin{array}{l}-0.000 \\
(-0.01)\end{array}$ \\
\hline Firm_Leverage & $\begin{array}{c}-7.544 * * * \\
(-7.37)\end{array}$ & $\begin{array}{c}-7.179 * * * \\
(-6.97)\end{array}$ & $\begin{array}{c}-6.773 * * * \\
(-6.53)\end{array}$ & $\begin{array}{c}-7.124 * * * \\
(-6.94)\end{array}$ \\
\hline Firm_Size (ln) & $\begin{array}{c}0.579 * * * \\
(3.64)\end{array}$ & $\begin{array}{c}0.743 * * * \\
(4.63)\end{array}$ & $\begin{array}{c}0.703 * * * \\
(3.93)\end{array}$ & $\begin{array}{c}0.770 * * * \\
(4.91)\end{array}$ \\
\hline Firm_Age (ln) & $\begin{array}{c}1.859 * * * \\
(4.18)\end{array}$ & $\begin{array}{c}2.023 * * * \\
(4.46)\end{array}$ & $\begin{array}{c}1.853 * * * \\
(3.82)\end{array}$ & $\begin{array}{c}2.253 * * * \\
(4.87)\end{array}$ \\
\hline Board_Size (Ln) & $\begin{array}{l}0.885 \\
(1.53)\end{array}$ & $\begin{array}{l}0.921 \\
(1.51)\end{array}$ & $\begin{array}{l}0.909 \\
(1.46)\end{array}$ & $\begin{array}{c}1.126+ \\
(1.82)\end{array}$ \\
\hline CEO_Duality & $\begin{array}{c}-0.714^{*} \\
(-2.42)\end{array}$ & $\begin{array}{l}-0.278 \\
(-0.87)\end{array}$ & $\begin{array}{l}-0.390 \\
(-1.16)\end{array}$ & $\begin{array}{l}-0.297 \\
(-0.93)\end{array}$ \\
\hline CEO_Age & $\begin{array}{l}0.005 \\
(0.30)\end{array}$ & $\begin{array}{l}-0.013 \\
(-0.65)\end{array}$ & $\begin{array}{l}-0.007 \\
(-0.32)\end{array}$ & $\begin{array}{l}-0.008 \\
(-0.41)\end{array}$ \\
\hline Family_CEO & & $\begin{array}{c}-2.069 * * * \\
(-4.81)\end{array}$ & $\begin{array}{c}-2.356^{* * * *} \\
(-3.85)\end{array}$ & $\begin{array}{c}-2.418^{* * *} \\
(-5.08)\end{array}$ \\
\hline CEO_Connected & & $\begin{array}{c}0.850+ \\
(1.74)\end{array}$ & $\begin{array}{l}0.827 \\
(1.20)\end{array}$ & $\begin{array}{l}0.390 \\
(0.76)\end{array}$ \\
\hline Board_Political_Connection_Intensity & & $\begin{array}{c}5.745+ \\
(1.75)\end{array}$ & $\begin{array}{l}4.478 \\
(1.19)\end{array}$ & $\begin{array}{l}3.067 \\
(0.75)\end{array}$ \\
\hline Family_CEO $*$ CEO_Connected & & & $\begin{array}{l}0.622 \\
(0.67)\end{array}$ & \\
\hline Family_CEO * Board_Political_Connection_Intensity & & & & $\begin{array}{c}10.424+ \\
(1.69)\end{array}$ \\
\hline _cons & $\begin{array}{c}-7.372+ \\
(-1.75) \\
\end{array}$ & $\begin{array}{c}-12.105^{* *} \\
(-2.72)\end{array}$ & $\begin{array}{c}-10.930 * \\
(-2.21)\end{array}$ & $\begin{array}{c}-13.972 * * \\
(-3.10)\end{array}$ \\
\hline Year fixed effects & Yes & Yes & Yes & Yes \\
\hline Industry fixed effects & Yes & Yes & Yes & Yes \\
\hline Wald Chi2 & 271.51 & 406.91 & 305.22 & 440.13 \\
\hline Observations & 402 & 402 & 402 & 402 \\
\hline Number of ID & 60 & 60 & 60 & 60 \\
\hline
\end{tabular}

$t$ statistics in parentheses

$+p<0.10, * p<0.05, * * p<0.01, * * * p<0.001$ 